\title{
Atmospheric Chemistry of Isopropyl Formate and tert-Butyl Formate
}

\author{
ANDRE SILVA PIMENTEL, ${ }^{1}$ GEOFFREY S. TYNDALL, ${ }^{2}$ JOHN J. ORLANDO, ${ }^{2}$ \\ MICHALE D. HURLEY, ${ }^{3}$ TIMOTHY J. WALLINGTON, ${ }^{3}$ MADS P. SULBAEK ANDERSEN, ${ }^{4}$ \\ PAUL MARSHALL, ${ }^{5}$ THEODORE S. DIBBLE ${ }^{6}$ \\ ${ }^{1}$ Departamento de Química, Pontificia Universidade Católica do Rio de Janeiro, Gávea 22453-900, Rio de Janeiro, RJ, Brazil \\ ${ }^{2}$ National Center for Atmospheric Research, P. O. Box 3000, Boulder, CO 80307 \\ ${ }^{3}$ Physical E Environmental Sciences Department, Ford Motor Company, Mail Drop SRL-3083, Dearborn, MI 48121 \\ ${ }^{4}$ Department of Chemistry, University of California, Irvine, Irvine, CA 92697 \\ ${ }^{5}$ Center for Advanced Scientific Computing and Modeling, Department of Chemistry, University of North Texas, \\ 1155 Union Circle, \#305070, Denton, TX 76203-5017 \\ ${ }^{6}$ Chemistry Department, State University of New York-Environmental Science and Forestry, Syracuse, NY 13210
}

Received 21 August 2009; revised 28 January 2010; accepted 3 March 2010

DOI 10.1002/kin.20498

Published online in Wiley InterScience (www.interscience.wiley.com).

\begin{abstract}
Formates are produced in the atmosphere as a result of the oxidation of a number of species, notably dialkyl ethers and vinyl ethers. This work describes experiments to define the oxidation mechanisms of isopropyl formate, $\mathrm{HC}(\mathrm{O}) \mathrm{OCH}\left(\mathrm{CH}_{3}\right)_{2}$, and tert-butyl formate, $\mathrm{HC}(\mathrm{O}) \mathrm{OC}\left(\mathrm{CH}_{3}\right)_{3}$. Product distributions are reported from both $\mathrm{Cl}$ - and $\mathrm{OH}$-initiated oxidation, and reaction mechanisms are proposed to account for the observed products. The proposed mechanisms include examples of the $\alpha$-ester rearrangement reaction, novel isomerization pathways, and chemically activated intermediates. The atmospheric oxidation of isopropyl formate by $\mathrm{OH}$ radicals gives the following products (molar yields): acetic formic anhydride (43\%), acetone $(43 \%)$, and $\mathrm{HCOOH}$ (15-20\%). The $\mathrm{OH}$ radical initiated oxidation of tert-butyl formate gives acetone, formaldehyde, and $\mathrm{CO}_{2}$ as major products. IR absorption cross sections were derived for two acylperoxy nitrates derived from the title compounds. Rate coefficients are derived for the kinetics of the reactions of isopropyl formate with $\mathrm{OH}(2.4 \pm 0.6) \times 10^{-12}$, and with $\mathrm{Cl}(1.75$ $\pm 0.35) \times 10^{-11}$, and for tert-butyl formate with $\mathrm{Cl}(1.45 \pm 0.30) \times 10^{-11} \mathrm{~cm}^{3}$ molecule $\mathrm{e}^{-1} \mathrm{~s}^{-1}$. Simple group additivity rules fail to explain the observed distribution of sites of H-atom abstraction for simple formates. (C) 2010 Wiley Periodicals, Inc. Int J Chem Kinet 42: 479-498, 2010
\end{abstract}

\section{INTRODUCTION}

Esters are oxygenated compounds that have recently been detected in the atmosphere [1]. They are used extensively as solvents and to provide the flavors and

Correspondence to: G. S. Tyndall; e-mail: tyndall@ucar.edu.

Figures S1-S3 are available as Supporting Information in the online issue at www.interscience.wiley.com.

(c) 2010 Wiley Periodicals, Inc. scents in certain household goods. Esters are formed in the atmospheric oxidation of ethers. For example, tertiary butyl formate (TBF) is produced in the oxidation of methyl tertiary butyl ether (MTBE) [2-4].

$$
\begin{aligned}
& \mathrm{CH}_{3} \mathrm{OC}\left(\mathrm{CH}_{3}\right)_{3}+\mathrm{OH} \rightarrow \mathrm{H}_{2} \mathrm{O}+{ }^{\bullet} \mathrm{CH}_{2} \mathrm{OC}\left(\mathrm{CH}_{3}\right)_{3} \\
& \cdot{ }^{\circ} \mathrm{CH}_{2} \mathrm{OC}\left(\mathrm{CH}_{3}\right)_{3}+\mathrm{O}_{2} \rightarrow \mathrm{O}_{2} \mathrm{CH}_{2} \mathrm{OC}\left(\mathrm{CH}_{3}\right)_{3}
\end{aligned}
$$




$$
\mathrm{O}_{2} \mathrm{CH}_{2} \mathrm{OC}\left(\mathrm{CH}_{3}\right)_{3}+\mathrm{NO} \rightarrow \mathrm{NO}_{2}+{ }^{\bullet} \mathrm{OCH}_{2} \mathrm{OC}\left(\mathrm{CH}_{3}\right)_{3}
$$

$\cdot \mathrm{OCH}_{2} \mathrm{OC}\left(\mathrm{CH}_{3}\right)_{3}+\mathrm{O}_{2} \rightarrow \mathrm{HC}(\mathrm{O}) \mathrm{OC}\left(\mathrm{CH}_{3}\right)_{3}+\mathrm{HO}_{2}$

MTBE has been used as a fuel additive to increase the oxygen content of fuel and hence reduce $\mathrm{CO}$ emissions. Although the use of MTBE has largely been discontinued in the United States, due to concerns about it contaminating ground water, it is still used in some other countries [5]. Thus, tert-butyl formate is a potentially important atmospheric chemical, particularly in areas where MTBE is still used [6]. It can also be formed from the atmospheric oxidation of ethyl tertiary butyl ether, which is replacing MTBE as a fuel additive, particularly in Europe.

The oxidation of vinyl ethers also leads to the formation of alkyl formates $[7,8]$.

$$
\begin{aligned}
\mathrm{OH}+\mathrm{CH}_{2}=\mathrm{CH}-\mathrm{OR} & \rightarrow \mathrm{HOCH}_{2}-\mathrm{C}^{\bullet} \mathrm{H}(\mathrm{OR})(5) \\
\mathrm{HOCH}_{2}-\mathrm{C}^{\bullet} \mathrm{H}(\mathrm{OR})+\mathrm{O}_{2} & \rightarrow \mathrm{HOCH}_{2}-\mathrm{CH}(\mathrm{OR}) \mathrm{O}_{2}
\end{aligned}
$$

$$
\begin{aligned}
\mathrm{HOCH}_{2}-\mathrm{CH}(\mathrm{OR}) \mathrm{O}_{2}+\mathrm{NO} \rightarrow & \mathrm{HOCH}_{2}-\mathrm{CH}(\mathrm{OR}) \mathrm{O}^{\bullet} \\
& +\mathrm{NO}_{2} \\
\mathrm{HOCH}_{2}-\mathrm{CH}(\mathrm{OR}) \mathrm{O}^{\bullet} \rightarrow & { }^{\bullet} \mathrm{CH}_{2} \mathrm{OH}+\mathrm{HC}(\mathrm{O}) \mathrm{OR}
\end{aligned}
$$

With the increased usage of ethers as oxygenated fuel additives in both gasoline and diesel engines [9], understanding the oxidation chemistry of esters takes on added importance. The esters studied in the current work can also be regarded as prototypes for larger, more complicated molecules formed from biofuels.

In addition to being environmentally important, esters are also of theoretical interest since the oxy radicals formed from them undergo a unique reaction, known as the alpha-ester rearrangement (where $\mathrm{R}$ and $\mathrm{R}^{\prime}$ represent either a $\mathrm{H}$-atom or an alkyl group).

$$
\mathrm{RC}(\mathrm{O}) \mathrm{O}-\mathrm{CHR}^{\prime} \mathrm{O}{ }^{\bullet} \rightarrow \mathrm{RC}(\mathrm{O}) \mathrm{OH}+\mathrm{R}^{\prime} \mathrm{C} \bullet \mathrm{O}
$$

This reaction was discovered by Tuazon et al. while studying the oxidation of ethyl acetate [10] and has since been shown to occur in a number of compounds that lead to a radical of the form $\mathrm{RC}(\mathrm{O}) \mathrm{O}-\mathrm{CHR}^{\prime} \mathrm{O}^{\bullet}$ [11-16]. The reaction involves transfer of a hydrogen atom from the carbon carrying the oxy radical to the oxygen of the carbonyl group $[17,18]$. The reaction appears to be accelerated by increasing substitution in either the acyl group $\mathrm{RC}(\mathrm{O})$ or the alkyl group $\mathrm{R}^{\prime}$, as a result of a reduced activation energy [19].

This work is part of a series of collaborative papers to investigate the mechanisms and thermochemistry of ester oxidation $[11,13,16,19]$. We report here experiments designed to study the chemistry of TBF, and the structurally related compound isopropyl formate (IPF). Rate coefficients are reported for the reactions of these two formates with chlorine atoms and for $\mathrm{OH}$ radicals with IPF; the product distributions from reaction with $\mathrm{Cl}$ atoms in the absence of $\mathrm{O}_{2}$ are described, from which the initial site of attack could be deduced; product studies in the presence of $\mathrm{NO}_{2}$ are used to identify the presence of peroxynitrate species; product distributions are reported for the $\mathrm{Cl}$-atom-initiated oxidation in mixtures containing $\mathrm{O}_{2}, \mathrm{NO}$, and $\mathrm{N}_{2}$, from which the behavior of the individual alkoxy radicals can be deduced. The atmospherically important reactions of IPF and TBF with $\mathrm{OH}$ radicals were also studied, and the branching ratios for $\mathrm{OH}$ attack were inferred from the observed product distributions. Theoretical quantum chemical calculations provided insight regarding the reaction mechanisms.

\section{EXPERIMENTAL}

Experiments were performed both at the National Center for Atmospheric Research (NCAR) and at the Research and Innovation Center of the Ford Motor Company. The experiments at NCAR were carried out in a cylindrical stainless steel chamber with a volume of $\sim 47 \mathrm{~L}[13,20]$. The chamber was interfaced to a Bomem DA3.01 Fourier transform infrared (FTIR) spectrometer. Internal multipass optics inside the chamber allowed an optical path length of $32 \mathrm{~m}$ for analysis of reactants and products. Photolysis was initiated using a filtered Xe arc lamp directed axially down the chamber through a quartz window. The experiments at Ford were carried out in a cylindrical Pyrex chamber of volume $\sim 127 \mathrm{~L}$ coupled to a Mattson Sirius FTIR spectrometer [13,21]. External blacklamps (GEF15T8-BL) provided the photolysis light for these experiments. Product yields were determined by the spectral subtraction of calibrated reference spectra recorded in each laboratory. Absorption cross sections (units of $\mathrm{cm}^{2}$ molecule ${ }^{-1}$ ) of the principal products were $\mathrm{HCOOH}, 8.5 \times 10^{-19}$ at $1119 \mathrm{~cm}^{-1}$; acetone, $2.5 \times 10^{-19}$ at $1231 \mathrm{~cm}^{-1}$; formic acetic anhydride (AFAN), $2.5 \times 10^{-18}$ at $1043 \mathrm{~cm}^{-1}$. The absorption spectra for $\mathrm{HCHO}, \mathrm{CO}$ and $\mathrm{CO}_{2}$ are all very structured, so absorption cross sections are not given here since they are instrument dependent. 
Most of the reactions described here were initiated by reaction of chlorine atoms with the esters, in the presence of nitric oxide, oxygen, and nitrogen. Chlorine atoms were produced by the photolysis of molecular chlorine.

$$
\begin{aligned}
\mathrm{Cl}_{2}+h v & \rightarrow \mathrm{Cl}+\mathrm{Cl} \\
\mathrm{Cl}+\mathrm{RH} & \rightarrow \mathrm{HCl}+\mathrm{R}^{\bullet} \\
\mathrm{R}^{\bullet}+\mathrm{O}_{2} & \rightarrow \mathrm{RO}_{2} \\
\mathrm{RO}_{2}+\mathrm{NO} & \rightarrow \mathrm{RO}+\mathrm{NO}_{2} \\
\mathrm{RO} & \rightarrow \text { products }
\end{aligned}
$$

Mixtures containing typically $\mathrm{Cl}_{2}(3-10) \times 10^{14}$ molecule $\mathrm{cm}^{-3}$, NO (3-6) $\times 10^{14}$ molecule $\mathrm{cm}^{-3}$ and either IPF or TBF $(2.4-5.0) \times 10^{14}$ molecule $\mathrm{cm}^{-3}$, and $\mathrm{O}_{2}$ (10-600 torr) made up to a total of 700 torr in nitrogen were irradiated for several periods of 2-3 min. Additional experiments were also done in the absence of NO. Infrared spectra were taken before and after each irradiation. After analysis of the spectra, product yields were obtained from plots of the amount of product formed against the amount of formate reacted. The stated uncertainties represent two standard deviations from unweighted least-squares regressions to the data.

By varying the concentration of oxygen in the chamber, information about the reaction pathway can often be gained since many alkoxy radicals react with oxygen in competition with a unimolecular reaction path, e.g.,

$$
\mathrm{HC}(\mathrm{O}) \mathrm{OCH}\left(\mathrm{CH}_{3}\right) \mathrm{O}^{\bullet} \rightarrow \mathrm{HC}(\mathrm{O}) \mathrm{OH}+\mathrm{CH}_{3} \mathrm{C}^{\bullet} \mathrm{O}
$$

$$
\begin{aligned}
\mathrm{HC}(\mathrm{O}) \mathrm{OCH}\left(\mathrm{CH}_{3}\right) \mathrm{O}^{\bullet}+\mathrm{O}_{2} \rightarrow & \mathrm{HC}(\mathrm{O}) \mathrm{OC}(\mathrm{O}) \mathrm{CH}_{3} \\
& +\mathrm{HO}_{2}
\end{aligned}
$$

Measurement of product ratios as a function of the $\mathrm{O}_{2}$ concentration can give quantitative information on the ratios of rate coefficients for such processes.

Experiments were also conducted to investigate the reaction mechanisms of IPF and TBF with $\mathrm{OH}$ radicals. A comparison was made with the products obtained from the $\mathrm{Cl}$-atom-initiated oxidation, which was studied more extensively. Hydroxyl radicals were generated using the photolysis of methyl (or ethyl) nitrite in the presence of $\mathrm{O}_{2}$ and $\mathrm{NO}$.

$$
\begin{aligned}
\mathrm{CH}_{3} \mathrm{ONO}+h v & \rightarrow \mathrm{CH}_{3} \mathrm{O}+\mathrm{NO} \\
\mathrm{CH}_{3} \mathrm{O}+\mathrm{O}_{2} & \rightarrow \mathrm{HCHO}+\mathrm{HO}_{2} \\
\mathrm{HO}_{2}+\mathrm{NO} & \rightarrow \mathrm{OH}+\mathrm{NO}_{2}
\end{aligned}
$$

The rate coefficients for the reactions of $\mathrm{Cl}$ atoms with IPF and TBF and for the reaction of $\mathrm{OH}$ with IPF were also measured as part of this work using the relative rate method.

\section{RESULTS}

\section{Relative Rate Studies}

The rate coefficients for the reactions of chlorine atoms with IPF (24) and TBF (25) were studied relative to methanol, ethyl chloride, and acetone. Chlorine atoms were produced in the presence of the ester and the reference compound in nitrogen bath gas.

$$
\begin{aligned}
\mathrm{Cl}+\mathrm{HC}(\mathrm{O}) \mathrm{OCH}\left(\mathrm{CH}_{3}\right)_{2} & \rightarrow \mathrm{HCl}+\text { products } \\
\mathrm{Cl}+\mathrm{HC}(\mathrm{O}) \mathrm{OC}\left(\mathrm{CH}_{3}\right)_{3} & \rightarrow \mathrm{HCl}+\text { products } \\
\mathrm{Cl}+\text { reference } & \rightarrow \text { products }
\end{aligned}
$$

Plots of $\ln$ [formate] vs. $\ln [$ reference] were linear with intercepts that were, within experimental uncertainty, equal to zero. The slope of the plot gives the ratio of rate coefficients $k_{24} / k_{26}$ (or analogously for $k_{25}$ ), according to Eq. (I).

$$
\begin{aligned}
& \ln \left(\left[\text { formate }_{\mathrm{o}} /\left[\text { formate }_{\mathrm{t}}\right)\right.\right. \\
& \quad=k_{24} / k_{26} \ln \left([\text { reference }]_{\mathrm{o}} /[\text { reference }]_{\mathrm{t}}\right)
\end{aligned}
$$

The results of the relative rate experiments are summarized in Table I.

In the case of the reaction of IPF with $\mathrm{Cl}$ atoms, the rate coefficient was measured relative to methanol. The slope of the plot (shown in Fig. 1) was $0.32 \pm 0.03$. Using the accepted value, $5.5 \times 10^{-11}$, for the reference rate coefficient [22] leads to $k_{24}=(1.75 \pm 0.35)$ $\times 10^{-11} \mathrm{~cm}^{3}$ molecule $\mathrm{s}^{-1}$, where the uncertainty is given as $\pm 20 \%$ to encompass the statistical error in the measurement and the uncertainty in the kinetics of the reference reaction. The rate coefficient for this reaction has not been measured previously. It is intermediate between the rate of reaction for ethyl formate $(0.96-1.34) \times 10^{-11}[23-25]$ and isopropyl acetate, $2.68 \times 10^{-11} \mathrm{~cm}^{3}$ molecule ${ }^{-1} \mathrm{~s}^{-1}$ [23], but considerably smaller than that for $n$-propyl formate (4.6-5.6) $\times$ $10^{-11} \mathrm{~cm}^{3}$ molecule ${ }^{-1} \mathrm{~s}^{-1}$ [23]. It should be noted that there is evidence that the rate coefficients reported by Notario et al. [23] are 20-30\% too high [25]; if so, the overall reactivity of IPF and isopropyl acetate would be indistinguishable.

The rate coefficient for reaction of $\mathrm{Cl}$ atoms with TBF was measured relative to acetone, ethyl chloride, and methanol. The slopes of the relative rate plots were 
Table I Summary of Relative Rate Measurements

\begin{tabular}{lcccc}
\hline Reaction & $\begin{array}{c}\text { Reference } \\
\text { Compound }\end{array}$ & $\begin{array}{c}\text { Relative } \\
\text { Rate }\end{array}$ & $\begin{array}{c}k_{\text {ref }}\left(\mathrm{cm}^{3}\right. \\
\text { molecule }\end{array}$ & $\begin{array}{c}10^{11} k^{a}\left(\mathrm{~cm}^{3}\right) \\
\left.\text { molecule }^{-1} \mathrm{~s}^{-1}\right)\end{array}$ \\
\hline $\mathrm{Cl}+\mathrm{IPF}$ & $\mathrm{CH}_{3} \mathrm{OH}$ & $0.32 \pm 0.03$ & $5.5 \times 10^{-11}$ & $1.75 \pm 0.35$ \\
$\mathrm{Cl}+\mathrm{TBF}$ & $\mathrm{CH}_{3} \mathrm{C}(\mathrm{O}) \mathrm{CH}_{3}$ & $6.55 \pm 0.65$ & $2.1 \times 10^{-12}$ & $1.38 \pm 0.14$ \\
$\mathrm{Cl}+\mathrm{TBF}$ & $\mathrm{CH}_{3} \mathrm{OH}$ & $0.24 \pm 0.03$ & $5.5 \times 10^{-11}$ & $1.30 \pm 0.16$ \\
$\mathrm{Cl}+\mathrm{TBF}$ & $\mathrm{C}_{2} \mathrm{H}_{5} \mathrm{Cl}^{b}$ & $1.92 \pm 0.15$ & $7.6 \times 10^{-12}$ & $1.47 \pm 0.12$ \\
$\mathrm{Cl}+\mathrm{TBF}$ & $\mathrm{CH}_{3} \mathrm{OH}^{b}$ & $0.29 \pm 0.02$ & $5.5 \times 10^{-11}$ & $1.57 \pm 0.11$ \\
$\mathrm{OH}+\mathrm{IPF}$ & $\mathrm{C}_{2} \mathrm{H}_{4}$ & $0.30 \pm 0.05$ & $7.9 \times 10^{-12}$ & $0.24 \pm 0.04$ \\
\hline
\end{tabular}

${ }^{a}$ Uncertainties in Table are $1-\sigma$ precision on each measurement. Final uncertainties are given in the text.

${ }^{b}$ Measurements at Ford. Otherwise at NCAR.

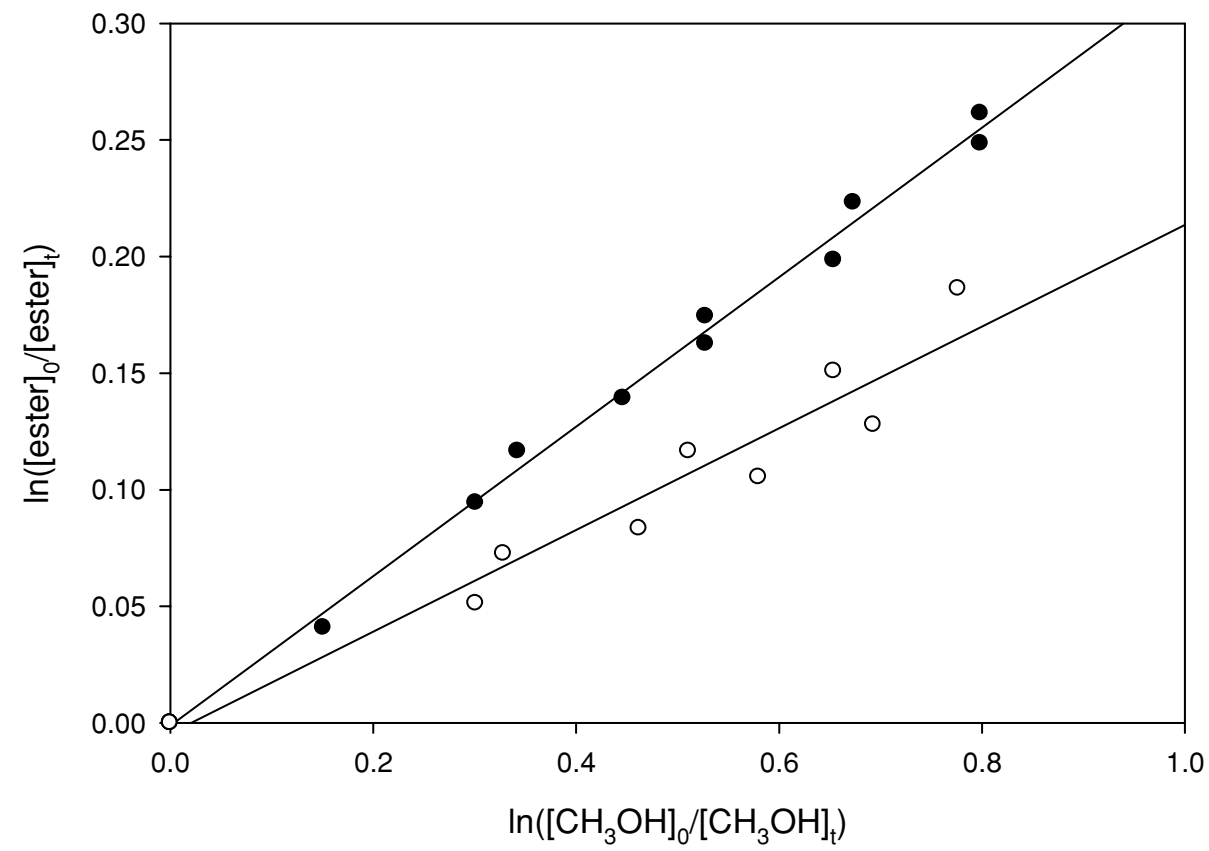

Figure 1 Plot of the relative rate equation for the reactions of chlorine atoms with IPF (๑) and tert-butyl formate (O), using methanol as the reference compound (NCAR data).

$6.55 \pm 0.65$ (acetone; NCAR), $0.24 \pm 0.03$ (methanol; NCAR), $1.92 \pm 0.15$ (ethyl chloride; Ford), and $0.29 \pm$ 0.02 (methanol; Ford). Data taken relative to methanol are included in Fig. 1. Using recent values for the rate coefficients for acetone $\left(2.1 \times 10^{-12}\right.$ [22] $)$, ethyl chloride $\left(7.6 \times 10^{-12}[26]\right)$, and methanol $\left(5.5 \times 10^{-11}\right.$ [22]) gives $k_{25}\left(10^{-11} \mathrm{~cm}^{3}\right.$ molecule $\left.{ }^{-1} \mathrm{~s}^{-1}\right)=1.38 \pm$ $0.14,1.30 \pm 0.16,1.47 \pm 0.12$, and $1.57 \pm 0.11$, respectively. Combining these results, we recommend $k_{25}=$ $(1.45 \pm 0.30) \times 10^{-11} \mathrm{~cm}^{3}$ molecule ${ }^{-1} \mathrm{~s}^{-1}$ at $298 \mathrm{~K}$. The rate coefficient has never been measured before. The value obtained for $k_{25}$ can be compared with that for tert-butyl acetate, $2.42 \times 10^{-11} \mathrm{~cm}^{3}$ molecule $^{-1}$ $\mathrm{s}^{-1}$ [23]. If the results reported by Notario et al. are indeed too high, the rate coefficients for reaction of $\mathrm{Cl}$ atoms with tert-butyl formate and tert-butyl acetate would be indistinguishable.
It will be shown in the next section that a considerable fraction of the reaction occurs at the formate group for both IPF and TBF. It is interesting that the rate coefficients for IPF and TBF are no faster than those for the corresponding acetates, in spite of the fact that reaction at the acetyl group in the acetates is expected to be negligible $[11,16]$.

The rate coefficient for reaction of OH with IPF was measured relative to that of ethene. The slope of the relative rate plot, shown in Fig. 2, was $0.30 \pm$ 0.05 . Combining this with the recommended value for $\mathrm{OH}+$ ethene at $P=1 \mathrm{~atm}, 7.9 \times 10^{-12} \mathrm{~cm}^{3}$ molecule $\mathrm{s}^{-1}$ [22], leads to the value $(2.4 \pm$ 0.6) $\times 10^{-12} \mathrm{~cm}^{3}$ molecule $\mathrm{s}^{-1} \mathrm{~s}^{-1}$ at $298 \mathrm{~K}$, where the uncertainty has been increased by an additional $10 \%$ to account for uncertainties in the reference reaction. 


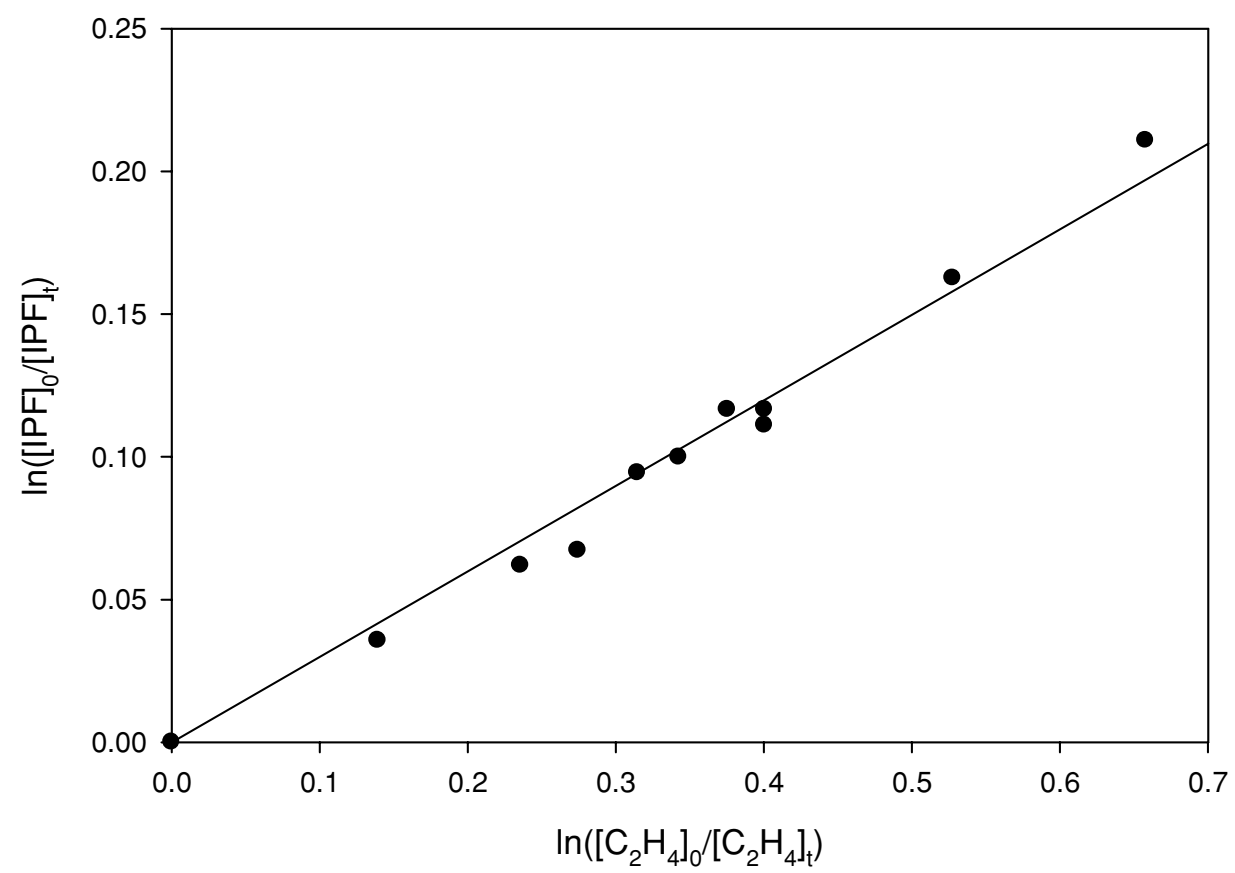

Figure 2 Plot of the relative rate equation for the reaction of OH radicals with IPF, using ethene as the reference compound.

There have been two previous determinations of this rate coefficient. Stemmler et al. [27] measured $(2.1 \pm 0.1) \times 10^{-12} \mathrm{~cm}^{3}$ molecule ${ }^{-1} \mathrm{~s}^{-1}$ using the relative rate technique with gas chromatographic detection, and dipropyl ether as the reference compound. Szilágyi et al. [28] measured $(1.88 \pm 0.08) \times$ $10^{-12} \mathrm{~cm}^{3}$ molecule $\mathrm{s}^{-1}$ using the discharge flow technique. Our value is a little higher than both these determinations, which may reflect the uncertainty in measuring the loss of IPF accurately using FTIR.

\section{Site of Attack}

The extent of attack of $\mathrm{Cl}$ atoms on the formyl group of IPF and TBF was determined using the chain reaction of the ester and $\mathrm{Cl} / \mathrm{Cl}_{2}$ in the absence of oxygen. The systems behaved somewhat differently, as described below.

$\mathrm{Cl}+$ Isopropyl Formate. The UV irradiation of $\mathrm{Cl}_{2}-$ IPF- $\mathrm{N}_{2}$ mixtures led to the appearance of a number of infrared features, including some in the characteristic $\mathrm{C}=\mathrm{O}$ stretching region of acyl chlorides $(1790 \pm$ $10 \mathrm{~cm}^{-1}$ ). By comparison with an authentic standard, significant yields were found for isopropyl chloroformate, $\mathrm{ClC}(\mathrm{O}) \mathrm{OCH}\left(\mathrm{CH}_{3}\right)_{2}$. Figure $\mathrm{S} 1$ in the Supporting Information shows yields of isopropyl chloroformate from the photolysis of mixtures containing (3-34) $\times$ $10^{14}$ molecule $\mathrm{cm}^{-3} \mathrm{Cl}_{2}$. The slope of the plot gives a yield of $0.30 \pm 0.03$, which corresponds to the fraction of attack at the formyl group in IPF. No $\mathrm{CO}$ or $\mathrm{CO}_{2}$ was seen for small conversions at $296 \mathrm{~K}$, indicating that the ${ }^{\bullet} \mathrm{C}(\mathrm{O}) \mathrm{OCH}\left(\mathrm{CH}_{3}\right)_{2}$ radical does not decompose via (28) or (29).

$$
\begin{gathered}
\mathrm{Cl}+\mathrm{HC}(\mathrm{O}) \mathrm{OCH}\left(\mathrm{CH}_{3}\right)_{2} \\
\rightarrow \mathrm{HCl}+{ }^{\bullet} \mathrm{C}(\mathrm{O}) \mathrm{OCH}\left(\mathrm{CH}_{3}\right)_{2} \\
\cdot \mathrm{C}(\mathrm{O}) \mathrm{OCH}\left(\mathrm{CH}_{3}\right)_{2}+\mathrm{Cl}_{2} \\
\rightarrow \mathrm{ClC}(\mathrm{O}) \mathrm{OCH}\left(\mathrm{CH}_{3}\right)_{2}+\mathrm{Cl} \\
{ }^{\bullet} \mathrm{C}(\mathrm{O}) \mathrm{OCH}\left(\mathrm{CH}_{3}\right)_{2} \rightarrow \mathrm{CO}_{2}+{ }^{\bullet} \mathrm{CH}\left(\mathrm{CH}_{3}\right)_{2} \\
{ }^{\cdot} \mathrm{C}(\mathrm{O}) \mathrm{OCH}\left(\mathrm{CH}_{3}\right)_{2} \rightarrow \mathrm{CO}+{ }^{\bullet} \mathrm{OCH}\left(\mathrm{CH}_{3}\right)_{2}
\end{gathered}
$$

Using the rate coefficient for $\mathrm{Cl}+\mathrm{IPF}$ derived above, $(1.75 \pm 0.35) \times 10^{-11} \mathrm{~cm}^{3}$ molecule ${ }^{-1} \mathrm{~s}^{-1}$, and a yield of isopropyl chloroformate of $30 \%$, implies a partial rate coefficient of $(5 \pm 2) \times 10^{-12} \mathrm{~cm}^{3}$ molecule ${ }^{-1} \mathrm{~s}^{-1}$ for reaction at the formyl group in IPF, where the error bar encompasses uncertainties in both the rate coefficient and the branching fraction. At $340 \mathrm{~K}, \mathrm{CO}_{2}$ was observed with a yield of $\sim 30 \%$, implying that thermal decomposition of the acyl radical to $\mathrm{CO}_{2}+$ isopropyl in reaction (28) was dominant at this temperature. In the presence of larger concentrations of $\mathrm{Cl}_{2}\left(>2 \times 10^{15}\right.$ molecule $\left.\mathrm{cm}^{-3}\right)$ isopropyl chloroformate could be observed, indicating that the 
acyloxy radicals were being trapped. No CO was observed at $340 \mathrm{~K}$.

$\boldsymbol{C l}+$ tert-Butyl Formate. Photolysis of $\mathrm{Cl}_{2}-\mathrm{TBF}-\mathrm{N}_{2}$ mixtures with less than $6 \times 10^{15}$ molecule $\mathrm{cm}^{-3} \mathrm{Cl}_{2}$ showed no evidence for the formation of an acyl chloride, but instead led to large yields of $\mathrm{CO}_{2}$. The yield of $\mathrm{CO}_{2}$ at low $\mathrm{Cl}_{2}$ was found to be $0.50 \pm 0.05$ (see Fig. S2 in the Supporting Information). This presumably corresponds to the fraction of attack at the formyl group, which is followed by decomposition of the resulting tert-butoxycarbonyl radical.

$$
\mathrm{Cl}+\mathrm{HC}(\mathrm{O}) \mathrm{OC}\left(\mathrm{CH}_{3}\right)_{3} \rightarrow \mathrm{HCl}+{ }^{\bullet} \mathrm{C}(\mathrm{O}) \mathrm{OC}\left(\mathrm{CH}_{3}\right)_{3}
$$

$$
{ }^{\bullet} \mathrm{C}(\mathrm{O}) \mathrm{OC}\left(\mathrm{CH}_{3}\right)_{3} \rightarrow \mathrm{CO}_{2}+{ }^{\bullet} \mathrm{C}\left(\mathrm{CH}_{3}\right)_{3}
$$

Using the rate coefficient for $\mathrm{Cl}+\mathrm{TBF}$ measured in this work, along with a $50 \%$ branching ratio, leads to a partial rate coefficient of $(7 \pm 2) \times 10^{-12} \mathrm{~cm}^{3}$ molecule $\mathrm{e}^{-1} \mathrm{~s}^{-1}$ for attack at the formyl group, similar to that in IPF. No CO was observed from the alternative dissociation pathway.

$$
\cdot \mathrm{C}(\mathrm{O}) \mathrm{OC}\left(\mathrm{CH}_{3}\right)_{3} \rightarrow \mathrm{CO}+{ }^{\bullet} \mathrm{OC}\left(\mathrm{CH}_{3}\right)_{3}
$$

On addition of larger amounts of $\mathrm{Cl}_{2}\left(\leq 2 \times 10^{17}\right.$ molecule $\mathrm{cm}^{-3}$ ) the acyl radicals were scavenged, and the $\mathrm{CO}_{2}$ yield $\mathrm{Y}\left(\mathrm{CO}_{2}\right)$ dropped smoothly from 0.5 to 0.08 .

$$
\cdot \mathrm{C}(\mathrm{O}) \mathrm{OC}\left(\mathrm{CH}_{3}\right)_{3}+\mathrm{Cl}_{2} \rightarrow \mathrm{ClC}(\mathrm{O}) \mathrm{OC}\left(\mathrm{CH}_{3}\right)_{3}+\mathrm{Cl}
$$

Assuming that the yield of tert-butyl chloroformate is given by $\left(0.5-\mathrm{Y}\left(\mathrm{CO}_{2}\right)\right)$, the competition for the tertbutoxy carbonyl radicals can be expressed as

$$
\frac{0.5-Y\left(\mathrm{CO}_{2}\right)}{Y\left(\mathrm{CO}_{2}\right)}=\frac{k_{33}\left[\mathrm{Cl}_{2}\right]}{k_{31}}
$$

A plot of $\left(0.5-\mathrm{Y}\left(\mathrm{CO}_{2}\right)\right) / \mathrm{Y}\left(\mathrm{CO}_{2}\right)$ versus $\left[\mathrm{Cl}_{2}\right]$ had a slope of $(2.8 \pm 0.7) \times 10^{-17} \mathrm{~cm}^{3}$ molecule $^{-1}$. Assuming that $k_{33}>10^{-11} \mathrm{~cm}^{3}$ molecule ${ }^{-1} \mathrm{~s}^{-1}$ [29], gives $k_{31}>3.6 \times 10^{5} \mathrm{~s}^{-1}$ at $296 \mathrm{~K}$. Rüegge and Fischer [30] measured the decomposition rate of ${ }^{\bullet} \mathrm{C}(\mathrm{O}) \mathrm{OC}\left(\mathrm{CH}_{3}\right)_{3}$ radicals directly in $\mathrm{n}$-heptane solution, using electron spin resonance analysis. They found $k_{31}=6.3 \times 10^{13}$ $\exp (-5900 / \mathrm{T}) \mathrm{s}^{-1}$, giving a rate coefficient of $1.4 \times$ $10^{5} \mathrm{~s}^{-1}$ at $296 \mathrm{~K}$.

In our previous study of chlorine atoms with methyl formate [13], the branching ratio for attack at the formyl group was $55 \%$. However, the overall rate coefficient for $\mathrm{Cl}+$ methyl formate is only $1.4 \times 10^{-12} \mathrm{~cm}^{3}$ molecule ${ }^{-1} \mathrm{~s}^{-1}$, giving a partial rate coefficient at the formyl group that is an order of magnitude smaller than that measured in the present work for the $\mathrm{Cl}+\mathrm{TBF}$ reaction. Thus it appears that simple group additivity cannot be used to predict the branching ratios for $\mathrm{Cl}$ attack on formates [23].

\section{Product Studies in the Presence of $\mathrm{O}_{2} / \mathrm{N}_{2} / \mathrm{NO}_{2}$}

We have previously shown that the oxidation of methyl formate in the presence of $\mathrm{NO}_{x}$ leads to the production of a peroxyacyl nitrate, which is useful in identifying the extent of reaction at the acyl site [11,13]. Here we report experiments to characterize the peroxynitrates from IPF and TBF, and to obtain their IR absorption cross sections. Reaction of $\mathrm{Cl}$ atoms with isopropyl and tert-butyl formate in air in the presence of $\mathrm{NO}_{2}$ led to the observation of numerous IR bands that could be associated with both alkylperoxy nitrates and acylperoxy nitrates. On addition of NO, bands at 1160,1303 , and $1720 \mathrm{~cm}^{-1}$ went away within the time it took to record a spectrum $(\sim 4 \mathrm{~min})$; these are attributed to alkyl peroxy nitrates, formed by attack at the alkyl group. Peroxyacyl nitrates derived from formates have characteristic IR absorption bands in the ranges $1230-1250$ and $1820-1850 \mathrm{~cm}^{-1}[13,21,31]$ and are more stable than the alkyl peroxy nitrates [13].

$$
\begin{aligned}
\mathrm{Cl}+\mathrm{HC}(\mathrm{O}) \mathrm{OR} & \rightarrow \mathrm{HCl}+\mathrm{ROC}^{\bullet} \mathrm{O} \\
\mathrm{ROC}^{\bullet} \mathrm{O}+\mathrm{O}_{2} & \rightarrow \mathrm{ROC}(\mathrm{O}) \mathrm{O}_{2} \\
\mathrm{ROC}(\mathrm{O}) \mathrm{O}_{2}+\mathrm{NO}_{2}+\mathrm{M} & \rightarrow \operatorname{ROC}(\mathrm{O}) \mathrm{O}_{2} \mathrm{NO}_{2}+\mathrm{M}
\end{aligned}
$$

In this work, the alkoxyformyl peroxy nitrates $\left(\mathrm{CH}_{3}\right)_{2} \mathrm{CHOC}(\mathrm{O}) \mathrm{O}_{2} \mathrm{NO}_{2}$ (iPOPAN) and $\left(\mathrm{CH}_{3}\right)_{3} \mathrm{COC}$ $(\mathrm{O}) \mathrm{O}_{2} \mathrm{NO}_{2}$ (tBOPAN) were identified as arising from the oxidation of IPF and TBF, respectively. These species decayed in the presence of NO with a lifetime of about $1 \mathrm{~h}$. At the conclusion of the experiments, absorption bands attributed to nitrites and nitrates could be seen in the spectra at 1160-1170 and 1290$1300 \mathrm{~cm}^{-1}$.

Upon addition of NO to the products from IPF, absorption features of AFAN, acetone and formic acid appeared rapidly. After decay of the unstable peroxynitrate(s), the residual bands (795, 910, 1109, 1233, 1745 , and $\left.1827 \mathrm{~cm}^{-1}\right)$ are assigned to the peroxyacyl nitrate $\left(\mathrm{CH}_{3}\right)_{2} \mathrm{CHOC}(\mathrm{O}) \mathrm{O}_{2} \mathrm{NO}_{2}$ (iPOPAN). Using the 
branching ratio derived earlier for reaction of $\mathrm{Cl}$ atoms at the formyl group (30\%) leads to peak infrared absorption cross sections for iPOPAN $\left(\mathrm{cm}^{2}\right.$ molecule $\left.{ }^{-1}\right)$ of $(5.2 \pm 0.8) \times 10^{-18}$ at $1233 \mathrm{~cm}^{-1},(3.1 \pm 0.5) \times$ $10^{-18}$ at $1745 \mathrm{~cm}^{-1}$, and $(1.9 \pm 0.3) \times 10^{-18}$ at $1827 \mathrm{~cm}^{-1}$. These cross sections are similar to those found in our previous work on the methoxy analog [13] and roughly a factor of 2 higher than the corresponding bands of peroxyacetyl nitrate (PAN) [32,33]. Formation of iPOPAN was also observed in experiments at $270 \mathrm{~K}$. The absorption cross sections of PAN change by less than $10 \%$ over this temperature range [33]. Assuming that iPOPAN cross sections are also independent of temperature, a yield of $30 \%$ is obtained, demonstrating that the branching fraction for $\mathrm{Cl}$-atom attack on the formyl site does not vary strongly with temperature.

Reaction of $\mathrm{Cl}$ atoms with TBF in the presence of $\mathrm{NO}_{2}$ in air led to the production of an alkyl peroxy nitrate and the acyl peroxy nitrate, $\left(\mathrm{CH}_{3}\right)_{3} \mathrm{COC}(\mathrm{O})$ $\mathrm{O}_{2} \mathrm{NO}_{2}$ (tBOPAN). This compound has been previously identified by Kirchner et al. [31]. Using a branching fraction of $(50 \pm 5) \%$ for reaction of $\mathrm{Cl}$ atoms at the formyl group, absorption cross sections $\left(\mathrm{cm}^{2}\right.$ molecule $\left.{ }^{-1}\right)$ of $(5.5 \pm 0.8) \times 10^{-18}$ at $1239 \mathrm{~cm}^{-1}$ and $(2.1 \pm 0.3) \times 10^{-18}$ at $1827 \mathrm{~cm}^{-1}$ were obtained for $\left(\mathrm{CH}_{3}\right)_{3} \mathrm{COC}(\mathrm{O}) \mathrm{O}_{2} \mathrm{NO}_{2}$.
Addition of NO led to the rapid decay of the alkyl peroxy nitrate, accompanied by production of $\mathrm{CO}_{2}$ and acetone. The tBOPAN decomposed with a $1 / e$ time of around $1 \mathrm{~h}$, somewhat slower than the 15-min lifetime reported by Kirchner et al. [31]. During the decay of tBOPAN, acetone was observed as a product. Figure 3 shows the products obtained during the dark decay of tBOPAN in the presence of excess NO. At the levels of $\mathrm{NO}$ and $\mathrm{NO}_{2}$ present, it would be expected that tert-butoxy radicals would be scavenged to form tert-butyl nitrite or tert-butyl nitrate [22]. However, acetone is found in a yield of $\sim 30 \%$ per tBOPAN decomposed (or $15 \%$ of the TBF reacted away), suggesting rapid decomposition of activated tert-butoxy radicals.

To compare the spectra of the peroxyacyl nitrates formed from methyl formate (MOPAN) [13], IPF (iPOPAN), and tert-butyl formate (tBOPAN), the infrared bands at $\sim 1230-1240 \mathrm{~cm}^{-1}$ were integrated. The integrated cross sections for the three molecules were $1.1 \times 10^{-16}, 8.0 \times 10^{-17}$, and $8.6 \times 10^{-17} \mathrm{~cm}$ molecule ${ }^{-1}$. Considering that a number of reference spectra have to be subtracted to obtain the residual absorptions, the values can be considered to be equal within the experimental uncertainties, showing consistency within the measurements of the branching fractions.

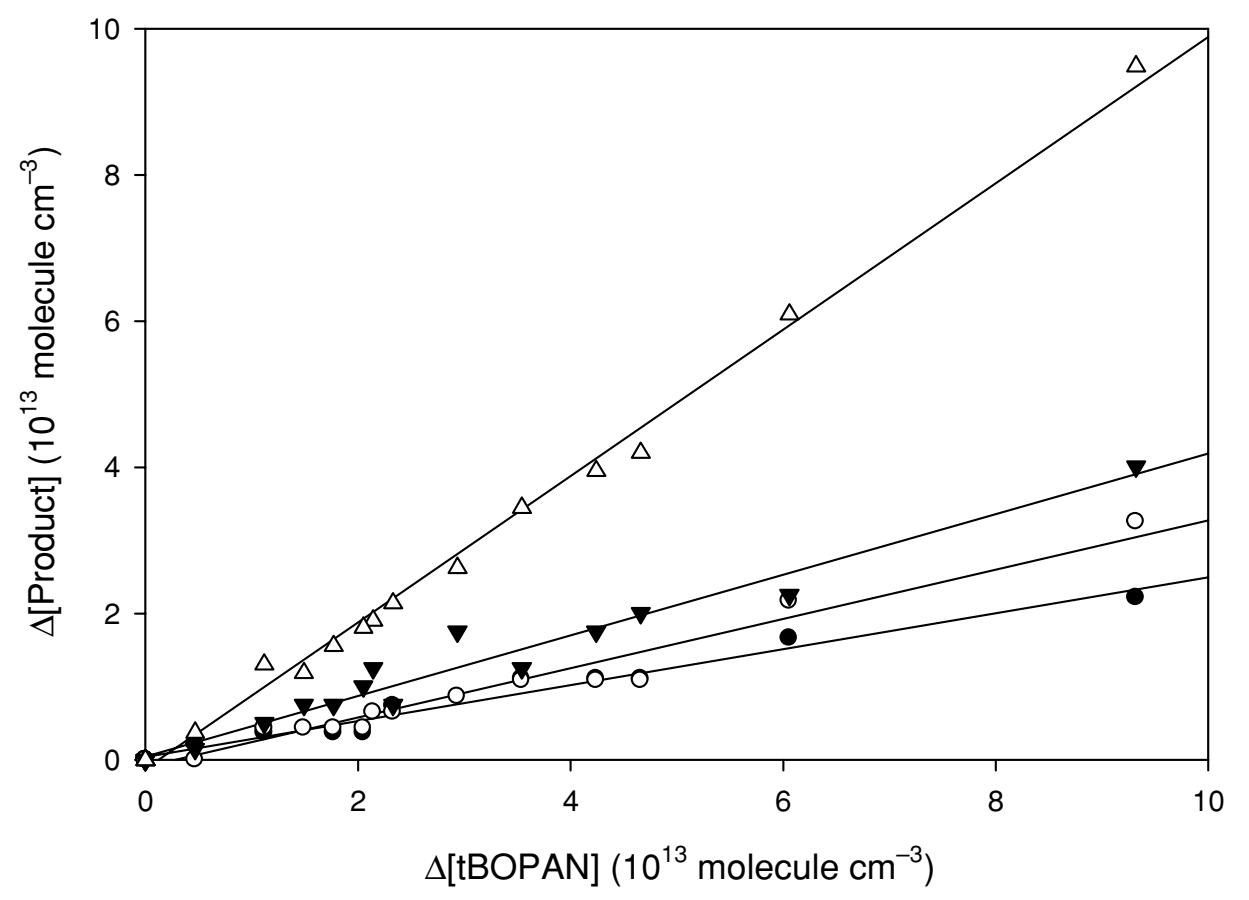

Figure 3 Product yields observed during the dark decay of tBOPAN in the presence of NO. $\bullet$, tert-BuONO; O, acetone; $\mathbf{\nabla}$, tert-BuONO $2 ; \square$, total. 


\section{Product Studies in the Presence of $\mathrm{O}_{2} / \mathrm{N}_{2} / \mathrm{NO}$}

Isopropyl Formate. Reaction of $\mathrm{Cl}$ atoms with IPF can occur by hydrogen atom abstraction at three sites, leading to the formation of three peroxy/oxy radicals.

$$
\begin{gathered}
\mathrm{Cl}+\mathrm{HC}(\mathrm{O}) \mathrm{OCH}\left(\mathrm{CH}_{3}\right)_{2}\left(+\mathrm{O}_{2}\right) \\
\rightarrow \mathrm{HCl}+\mathrm{O}_{2} \mathrm{C}(\mathrm{O}) \mathrm{OCH}\left(\mathrm{CH}_{3}\right)_{2} \\
\mathrm{O}_{2} \mathrm{C}(\mathrm{O}) \mathrm{OCH}\left(\mathrm{CH}_{3}\right)_{2}+\mathrm{NO} \\
\rightarrow \mathrm{NO}_{2}+\mathrm{CO}_{2}+{ }^{\bullet} \mathrm{OCH}\left(\mathrm{CH}_{3}\right)_{2} \\
\mathrm{Cl}+\mathrm{HC}(\mathrm{O}) \mathrm{OCH}\left(\mathrm{CH}_{3}\right)_{2}\left(+\mathrm{O}_{2}\right) \\
\rightarrow \mathrm{HCl}+\mathrm{HC}(\mathrm{O}) \mathrm{OC}\left(\mathrm{CH}_{3}\right)_{2} \mathrm{O}_{2} \\
\mathrm{HC}(\mathrm{O}) \mathrm{OC}\left(\mathrm{CH}_{3}\right)_{2} \mathrm{O}_{2}+\mathrm{NO} \\
\rightarrow \mathrm{NO}_{2}+\mathrm{HC}(\mathrm{O}) \mathrm{OC}\left(\mathrm{CH}_{3}\right)_{2} \mathrm{O}^{\bullet} \\
\mathrm{Cl}+\mathrm{HC}(\mathrm{O}) \mathrm{OCH}\left(\mathrm{CH}_{3}\right)_{2}\left(+\mathrm{O}_{2}\right) \\
\rightarrow \mathrm{HCl}+\mathrm{HC}(\mathrm{O}) \mathrm{OCH}_{\left(\mathrm{CH}_{3}\right) \mathrm{CH}_{2} \mathrm{O}_{2}} \\
\mathrm{HC}(\mathrm{O}) \mathrm{OCH}(\mathrm{CH})_{3} \mathrm{CH}_{2} \mathrm{O}_{2}+\mathrm{NO}^{2} \\
\rightarrow \mathrm{NO}_{2}+\mathrm{HC}(\mathrm{O}) \mathrm{OCH}\left(\mathrm{CH}_{3}\right) \mathrm{CH}_{2} \mathrm{O}^{\bullet}
\end{gathered}
$$

The oxidation of IPF was studied in the presence of NO at a total pressure of 700 torr, with the partial pressure of $\mathrm{O}_{2}$ varied between 20 and 450 torr. Experiments were also conducted using mixtures containing zero $\mathrm{NO}$ and at $270 \mathrm{~K}$. The major products observed in all experiments were $\mathrm{HCHO}, \mathrm{CO}, \mathrm{CO}_{2}, \mathrm{HCOOH}$, acetic formic anhydride $\left(\mathrm{AFAN}, \mathrm{HC}(\mathrm{O}) \mathrm{OC}(\mathrm{O}) \mathrm{CH}_{3}\right)$, acetone $\left(\mathrm{CH}_{3} \mathrm{C}(\mathrm{O}) \mathrm{CH}_{3}\right)$, and the acyl peroxy nitrate iPOPAN $\left(\left(\mathrm{CH}_{3}\right)_{2} \mathrm{CHOC}(\mathrm{O}) \mathrm{O}_{2} \mathrm{NO}_{2}\right)$. The major pathways in the oxidation of IPF leading to these products are summarized in the lower half of Reaction Scheme 1 later in this paper.

Representative product data in air are shown in Fig. 4, and yields of the observed products for a variety of starting conditions are given in Table II. Product yields measured at short reaction times (i.e., small extent of conversion) were not found to be strongly dependent on the $\mathrm{O}_{2}$ partial pressure. Data from experiments at different $\mathrm{O}_{2}$ partial pressures were combined to give yields of acetone $(30 \pm 5 \%)$, AFAN $(30 \pm 4 \%)$, formic acid $(15 \pm 5 \%)$, and $\mathrm{CO}_{2}(52 \pm 8 \%)$. The yield plots of acetone and $\mathrm{CO}_{2}$ versus $\triangle(\mathrm{IPF})$ were found to curve downward at high conversion, as the iPOPAN yield increased. This was a result of competition for the acyl peroxy radical $\left(\mathrm{CH}_{3}\right)_{2} \mathrm{CHOC}(\mathrm{O}) \mathrm{O}_{2}$ reacting with either $\mathrm{NO}$ or $\mathrm{NO}_{2}$. A plot of [acetone] + [iPOPAN] was linear with a slope of $0.38 \pm 0.05$. The sum of the yields of acetone, AFAN, $\mathrm{HCOOH}$ and iPOPAN was between 75 and $85 \%$, accounting for most of the reacted IPF. Some of the run-to-run variability in the

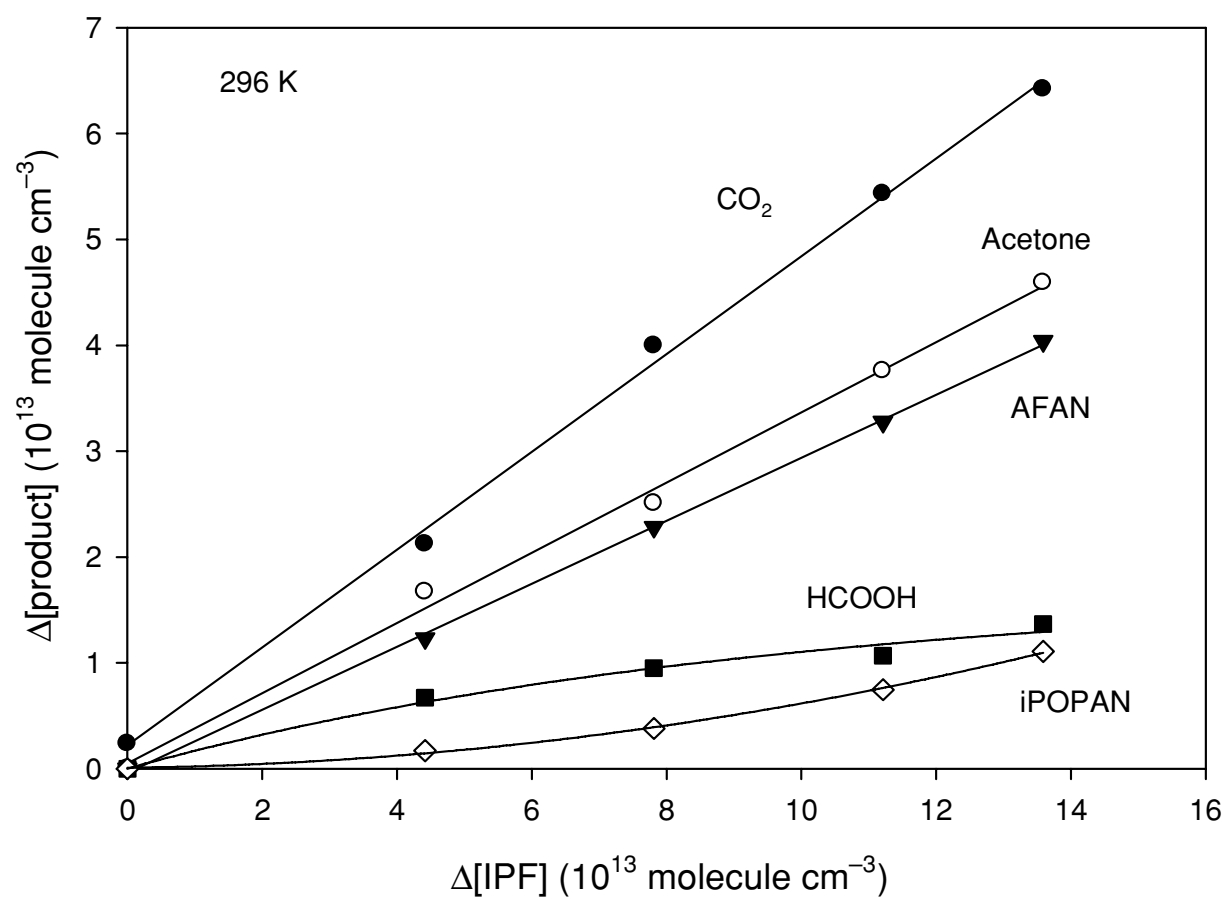

Figure 4 Formation of products from the reaction of $\mathrm{Cl}$ atoms with IPF in the presence of NO $\left(5.5 \times 10^{14} \mathrm{molecule}^{-3}\right)$ and 140 torr $\mathrm{O}_{2}$ (made up to 700 torr with $\mathrm{N}_{2}$ ) at $296 \mathrm{~K}$. $\bullet, \mathrm{CO}_{2} ;$ O, acetone; $\mathbf{\nabla}, \mathrm{AFAN} ; \boldsymbol{\square}, \mathrm{HCOOH} ; \diamond, \mathrm{POPAN}$. 
Table II Experimental Conditions and Product Yields for the Reaction of IPF with $\mathrm{Cl}$ Atoms in the Presence of NO

\begin{tabular}{|c|c|c|c|c|c|c|c|c|c|}
\hline \multirow[b]{2}{*}{$\begin{array}{l}\mathrm{P}\left(\mathrm{O}_{2}\right) \\
\text { (torr) }\end{array}$} & \multirow[b]{2}{*}{$\begin{array}{c}{[\mathrm{IPF}] \mathrm{o}} \\
\left(\times 10^{14}\right)\end{array}$} & \multirow[b]{2}{*}{$\begin{array}{c}{[\mathrm{NO}] \mathrm{o}} \\
\left(\times 10^{14}\right)\end{array}$} & \multicolumn{7}{|c|}{ Product Yields (\%) } \\
\hline & & & $\mathrm{CO}_{2}$ & $\begin{array}{c}\mathrm{CO}_{2}+ \\
\text { iPOPAN }\end{array}$ & Acetone & $\begin{array}{c}\text { Acetone + } \\
\text { iPOPAN }\end{array}$ & AFAN & $\mathrm{HCOOH}$ & $\begin{array}{l}\mathrm{CO}+ \\
\mathrm{HCHO}\end{array}$ \\
\hline 140 & 3.5 & 5.6 & 59 & 65 & 33 & 38 & 27 & 8 & 37 \\
\hline 450 & 3.5 & 5.6 & 52 & 56 & 32 & 41 & 30 & 10 & 36 \\
\hline 150 & 3.5 & 5.6 & 64 & 71 & 25 & 32 & 30 & 12 & 35 \\
\hline 450 & 3.5 & 6.5 & 41 & 51 & 27 & 35 & 28 & 12 & 32 \\
\hline 20 & 3.5 & 6.8 & 51 & 58 & 28 & 32 & 27 & 18 & 24 \\
\hline 140 & 3.4 & 5.5 & 48 & 56 & 34 & 42 & 30 & 15 & 33 \\
\hline 20 & 3.4 & 5.5 & 50 & 59 & 30 & 37 & 29 & 14 & 28 \\
\hline 450 & 3.4 & 5.5 & 39 & 50 & 28 & 38 & 31 & 10 & 35 \\
\hline $140^{a}$ & 3.5 & 5.4 & 37 & 46 & 45 & 53 & 16 & 20 & 10 \\
\hline $20^{a}$ & 3.5 & 5.4 & 38 & 44 & 45 & 51 & 16 & 20 & 15 \\
\hline $400^{a}$ & 3.5 & 5.2 & 34 & 44 & 41 & 51 & 19 & 19 & 11 \\
\hline
\end{tabular}

${ }^{a}$ Expt. at $270 \mathrm{~K}$.

yields is caused by differences in secondary chemistry as the ratios $\mathrm{O}_{2} / \mathrm{NO}_{x}$ and $\mathrm{NO} / \mathrm{NO}_{2}$ varied. Interestingly, there was no obvious dependence of the acetone yield on the ratio $\left[\mathrm{O}_{2}\right] /[\mathrm{NO}]$ nor was there any strong evidence for the formation of isopropyl nitrite or nitrate. These observations will be further discussed later.

The yields of $\mathrm{CO}$ and $\mathrm{HCHO}$ were combined, since the very rapid reaction of $\mathrm{HCHO}$ with $\mathrm{Cl}$ atoms converts it to $\mathrm{CO}$.

$$
\begin{gathered}
\mathrm{Cl}+\mathrm{HCHO} \rightarrow \mathrm{HCl}+\mathrm{HCO} \\
\mathrm{HCO}+\mathrm{O}_{2} \rightarrow \mathrm{HO}_{2}+\mathrm{CO}
\end{gathered}
$$

At high $\left[\mathrm{O}_{2}\right]$ the yield of $\mathrm{CO}+\mathrm{HCHO}$ was $40 \%$. At low $\mathrm{O}_{2}$ (20 torr) methyl nitrite and methyl nitrate were also observed, indicating that part of the $\mathrm{HCHO}$ originated from $\mathrm{CH}_{3} \mathrm{O}$ radicals.

$$
\begin{aligned}
\mathrm{CH}_{3} \mathrm{O}+\mathrm{O}_{2} & \rightarrow \mathrm{HCHO}+\mathrm{HO}_{2} \\
\mathrm{CH}_{3} \mathrm{O}+\mathrm{NO}+\mathrm{M} & \rightarrow \mathrm{CH}_{3} \mathrm{ONO}+\mathrm{M} \\
\mathrm{CH}_{3} \mathrm{O}+\mathrm{NO}_{2}+\mathrm{M} & \rightarrow \mathrm{CH}_{3} \mathrm{ONO}_{2}+\mathrm{M}
\end{aligned}
$$

The variation of the sum $\left(\mathrm{CH}_{3} \mathrm{ONO}+\mathrm{CH}_{3} \mathrm{ONO}_{2}\right)$ with $\mathrm{O}_{2}$ concentration was consistent with the known rate coefficients for reactions (18), (38), and (39) [22] and led to a $\mathrm{CH}_{3} \mathrm{O}$ yield of $(35 \pm 5) \%$. The total yield of $(\mathrm{HCHO}+$ methyl nitrate + methyl nitrite) approached $55 \%$, implying a direct $\mathrm{HCHO}$ yield close to $20 \%$. The most likely direct source of $\mathrm{HCHO}$ is from decomposition of the $\mathrm{HC}(\mathrm{O}) \mathrm{OCH}\left(\mathrm{CH}_{3}\right) \mathrm{CH}_{2} \mathrm{O}^{\bullet}$ radical (40); no spectral features were identified which could be attributed to 2-formoxypropanal from its reaction with $\mathrm{O}_{2}(41)$.

$$
\begin{aligned}
& \mathrm{HC}(\mathrm{O}) \mathrm{OCH}\left(\mathrm{CH}_{3}\right) \mathrm{CH}_{2} \mathrm{O}^{\bullet} \\
& \quad \rightarrow \mathrm{HC}(\mathrm{O}) \mathrm{OC}^{\bullet} \mathrm{H}\left(\mathrm{CH}_{3}\right)+\mathrm{HCHO} \\
& \mathrm{HC}(\mathrm{O}) \mathrm{OCH}\left(\mathrm{CH}_{3}\right) \mathrm{CH}_{2} \mathrm{O}^{\bullet}+\mathrm{O}_{2} \\
& \quad \rightarrow \mathrm{HO}_{2}+\mathrm{HC}(\mathrm{O}) \mathrm{OCH}\left(\mathrm{CH}_{3}\right) \mathrm{CHO}
\end{aligned}
$$

The inferred yield of methyl radicals $(\sim 35 \%)$ was very close to that of AFAN, suggesting a common source from the $\mathrm{HC}(\mathrm{O}) \mathrm{OC}\left(\mathrm{CH}_{3}\right)_{2} \mathrm{O}^{\bullet}$ radical.

$$
\mathrm{HC}(\mathrm{O}) \mathrm{OC}\left(\mathrm{CH}_{3}\right)_{2} \mathrm{O} \bullet \rightarrow \mathrm{HC}(\mathrm{O}) \mathrm{OC}(\mathrm{O}) \mathrm{CH}_{3}+\mathrm{CH}_{3}
$$

Oxidation at the formyl group in IPF (reaction (24a)) should lead to the isopropoxy radical, which is known to react with $\mathrm{O}_{2}$ to produce acetone.

$$
\begin{gathered}
\mathrm{O}_{2} \mathrm{C}(\mathrm{O}) \mathrm{OCH}\left(\mathrm{CH}_{3}\right)_{2}+\mathrm{NO} \\
\rightarrow \mathrm{NO}_{2}+\mathrm{CO}_{2}+\left(\mathrm{CH}_{3}\right)_{2} \mathrm{CHO}^{\bullet} \\
\left(\mathrm{CH}_{3}\right)_{2} \mathrm{CHO}^{\bullet}+\mathrm{O}_{2} \rightarrow \mathrm{HO}_{2}+\mathrm{CH}_{3} \mathrm{C}(\mathrm{O}) \mathrm{CH}_{3}
\end{gathered}
$$

However, reaction (43) cannot be the only source of acetone, since the yield of acetone plus iPOPAN exceeds $30 \%$, which is the fraction of abstraction at the $\mathrm{H}-\mathrm{C}(\mathrm{O})$ bond determined earlier. Furthermore, acetone was formed from decomposition of the unstable alkylperoxy nitrates (see the section Product Studies in the Presence of $\mathrm{O}_{2} / \mathrm{N}_{2} / \mathrm{NO}_{2}$ ). It is proposed that decomposition of the tertiary alkoxy radical $\mathrm{HC}(\mathrm{O}) \mathrm{OC}\left(\mathrm{CH}_{3}\right)_{2} \mathrm{O}^{\bullet}$ leads to the formation of either 
AFAN (42) or acetone (44)-(46). Direct decomposition to give acetone and $\mathrm{HCO}_{2}$ is also possible (47), but such $\mathrm{C}-\mathrm{O}$ bond fissions are thought to have a higher barrier and are not expected to occur at $296 \mathrm{~K}[17,18,34,35]$.

$$
\mathrm{HC}(\mathrm{O}) \mathrm{OC}\left(\mathrm{CH}_{3}\right)_{2} \mathrm{O}^{\bullet} \rightarrow \mathrm{CH}_{3}+\mathrm{HC}(\mathrm{O}) \mathrm{OC}(\mathrm{O}) \mathrm{CH}_{3}
$$

$$
\begin{aligned}
\mathrm{HC}(\mathrm{O}) \mathrm{OC}\left(\mathrm{CH}_{3}\right)_{2} \mathrm{O}^{\bullet} & \rightarrow{ }^{\bullet} \mathrm{C}(\mathrm{O}) \mathrm{OC}\left(\mathrm{CH}_{3}\right)_{2} \mathrm{OH} \\
{ }^{\bullet} \mathrm{C}(\mathrm{O}) \mathrm{OC}\left(\mathrm{CH}_{3}\right)_{2} \mathrm{OH} & \rightarrow \mathrm{CO}_{2}+{ }^{\bullet} \mathrm{C}\left(\mathrm{CH}_{3}\right)_{2} \mathrm{OH} \\
{ }^{\bullet} \mathrm{C}\left(\mathrm{CH}_{3}\right)_{2} \mathrm{OH}+\mathrm{O}_{2} & \rightarrow \mathrm{HO}_{2}+\mathrm{CH}_{3} \mathrm{C}(\mathrm{O}) \mathrm{CH}_{3} \\
\mathrm{HC}(\mathrm{O}) \mathrm{OC}\left(\mathrm{CH}_{3}\right)_{2} \mathrm{O}^{\bullet} & \rightarrow \mathrm{HCO}_{2}+\mathrm{CH}_{3} \mathrm{C}(\mathrm{O}) \mathrm{CH}_{3}
\end{aligned}
$$

The combined yields of acetone and iPOPAN total 35-40\%. Since abstraction at the formyl site accounts for only $30 \%$, the additional acetone must come from the tertiary site. Decomposition of the $\mathrm{HC}(\mathrm{O}) \mathrm{OC}\left(\mathrm{CH}_{3}\right)_{2} \mathrm{O}^{\bullet}$ radical thus produces AFAN $(30 \pm 5 \%)$ and acetone $(10 \pm 5 \%)$. The observation that acetone was formed from the decomposition of the alkyl peroxy nitrates (see the section Product Studies in the Presence of $\mathrm{O}_{2} / \mathrm{N}_{2} / \mathrm{NO}_{2}$ ) is very strong evidence for the occurrence of reactions (44) and/or (47). It will be argued later that the product distribution largely results from chemical activation of the radicals, rather than a thermal distribution.

The remaining abstraction occurs at the primary methyl groups, leading to the production of formic acid through the $\alpha$-ester rearrangement (15).

$$
\begin{aligned}
& \mathrm{HC}(\mathrm{O}) \mathrm{OCH}\left(\mathrm{CH}_{3}\right) \mathrm{CH}_{2} \mathrm{O}_{2}+\mathrm{NO} \\
& \rightarrow \mathrm{NO}_{2}+\mathrm{HC}(\mathrm{O}) \mathrm{OCH}\left(\mathrm{CH}_{3}\right) \mathrm{CH}_{2} \mathrm{O}^{\bullet} \\
& \mathrm{HC}(\mathrm{O}) \mathrm{OCH}\left(\mathrm{CH}_{3}\right) \mathrm{CH}_{2} \mathrm{O}^{\bullet} \\
& \rightarrow \mathrm{HCHO}+\mathrm{HC}(\mathrm{O}) \mathrm{OC}^{\bullet} \mathrm{H}\left(\mathrm{CH}_{3}\right) \\
& \mathrm{HC}(\mathrm{O}) \mathrm{OC}^{\bullet} \mathrm{H}\left(\mathrm{CH}_{3}\right)+\mathrm{O}_{2} \\
& \rightarrow \mathrm{HC}(\mathrm{O}) \mathrm{OCH}\left(\mathrm{CH}_{3}\right) \mathrm{O}_{2} \\
& \mathrm{HC}(\mathrm{O}) \mathrm{OCH}\left(\mathrm{CH}_{3}\right) \mathrm{O}_{2}+\mathrm{NO} \\
& \rightarrow \mathrm{HC}(\mathrm{O}) \mathrm{OCH}\left(\mathrm{CH}_{3}\right) \mathrm{O}^{\bullet}+\mathrm{NO}_{2} \\
& \mathrm{HC}(\mathrm{O}) \mathrm{OCH}\left(\mathrm{CH}_{3}\right) \mathrm{O}^{\bullet} \rightarrow \mathrm{HC}(\mathrm{O}) \mathrm{OH}+\mathrm{CH}_{3} \mathrm{C}^{\bullet} \mathrm{O}
\end{aligned}
$$

The $\mathrm{HC}(\mathrm{O}) \mathrm{OCH}\left(\mathrm{CH}_{3}\right) \mathrm{O}^{\bullet}$ radical is also formed in the oxidation of ethyl formate $[19,36]$. It has five available reaction pathways: reaction with $\mathrm{O}_{2}$, elimination of $-\mathrm{CH}_{3}, \mathrm{C}-\mathrm{O}$ dissociation, isomerization through a five-membered transition state, and the alpha-ester rearrangement. Orlando and Tyndall [19] have shown that this radical reacts predominantly by the $\alpha$-ester reaction at room temperature, in competition with reaction with $\mathrm{O}_{2}$. The ratio of rate coefficients found at room temperature in that work was $k_{15} / k_{16}=4 \times 10^{19}$ molecule $\mathrm{cm}^{-3}$. Assuming a rate coefficient for reaction (16) of $1 \times 10^{-14} \mathrm{~cm}^{3}$ molecule ${ }^{-1} \mathrm{~s}^{-1}$ leads to a decomposition rate of $4 \times 10^{5} \mathrm{~s}^{-1}$; however, there is evidence to suspect that reactions of alkoxy radicals with $\mathrm{O}_{2}$ that are highly exothermic such as (16) may be faster than the canonical value given above [34].

$$
\begin{aligned}
& \mathrm{HC}(\mathrm{O}) \mathrm{OCH}\left(\mathrm{CH}_{3}\right) \mathrm{O}^{\bullet} \rightarrow \mathrm{HCOOH}+\mathrm{CH}_{3} \mathrm{CO} \\
& \mathrm{HC}(\mathrm{O}) \mathrm{OCH}\left(\mathrm{CH}_{3}\right) \mathrm{O}^{\bullet}+\mathrm{O}_{2} \\
& \quad \rightarrow \mathrm{HC}(\mathrm{O}) \mathrm{OC}(\mathrm{O}) \mathrm{CH}_{3}+\mathrm{HO}_{2}
\end{aligned}
$$

The observed yield of formic acid was 15-20\% at short reaction times, consistent with the direct formaldehyde yield. The yields of $\mathrm{HCOOH}$ given in Table II show only a weak dependence on $\mathrm{O}_{2}$, consistent with the large value of $k_{15} / k_{16}$ given above. The $\mathrm{HCOOH}$ yield decreased as the reaction proceeded (see Fig. 4), which is probably a consequence of a precursor to formic acid being scavenged by $\mathrm{NO}_{2}$, which builds up during the course of an experiment. The concentration of $\mathrm{NO}_{2}$ builds up faster at higher $\mathrm{O}_{2}$ (because of the reaction $\mathrm{NO}+\mathrm{NO}+\mathrm{O}_{2}$ ), which could account for some of the apparent $\mathrm{O}_{2}$ dependence. The yields of acetone + iPOPAN + AFAN + formic acid add up to $(82 \pm 15 \%)$, accounting for most of the reacted carbon. Some formation of large, multifunctional organic nitrates was observed, which could account for the rest of the reaction. Peroxyacetyl nitrate should also be produced from the acetyl radicals formed in reaction (15). However, its most prominent IR band, at $1164 \mathrm{~cm}^{-1}$, was obscured by the multifunctional nitrates. No evidence was found for production of formic anhydride, the product of reaction (50).

$$
\mathrm{HC}(\mathrm{O}) \mathrm{OCH}\left(\mathrm{CH}_{3}\right) \mathrm{O}^{\bullet} \rightarrow \mathrm{HC}(\mathrm{O}) \mathrm{OCHO}+\mathrm{CH}_{3}
$$

As the reaction proceeds, $\mathrm{NO}$ is converted to $\mathrm{NO}_{2}$. The variation of the $\mathrm{NO} / \mathrm{NO}_{2}$ ratio during the course of an experiment (0.3-6) allowed an estimation of the relative rate coefficients for the reactions of the acyl peroxy radical with $\mathrm{NO}$ and $\mathrm{NO}_{2}$.

$$
\begin{aligned}
& \left(\mathrm{CH}_{3}\right)_{2} \mathrm{CHOC}(\mathrm{O}) \mathrm{O}_{2}+\mathrm{NO} \\
& \rightarrow \mathrm{NO}_{2}+\mathrm{CO}_{2}+\left(\mathrm{CH}_{3}\right)_{2} \mathrm{CHO} \bullet \\
& \left(\mathrm{CH}_{3}\right)_{2} \mathrm{CHOC}(\mathrm{O}) \mathrm{O}_{2}+\mathrm{NO}_{2} \\
& \quad \rightarrow\left(\mathrm{CH}_{3}\right)_{2} \mathrm{CHOC}(\mathrm{O}) \mathrm{O}_{2} \mathrm{NO}_{2}
\end{aligned}
$$




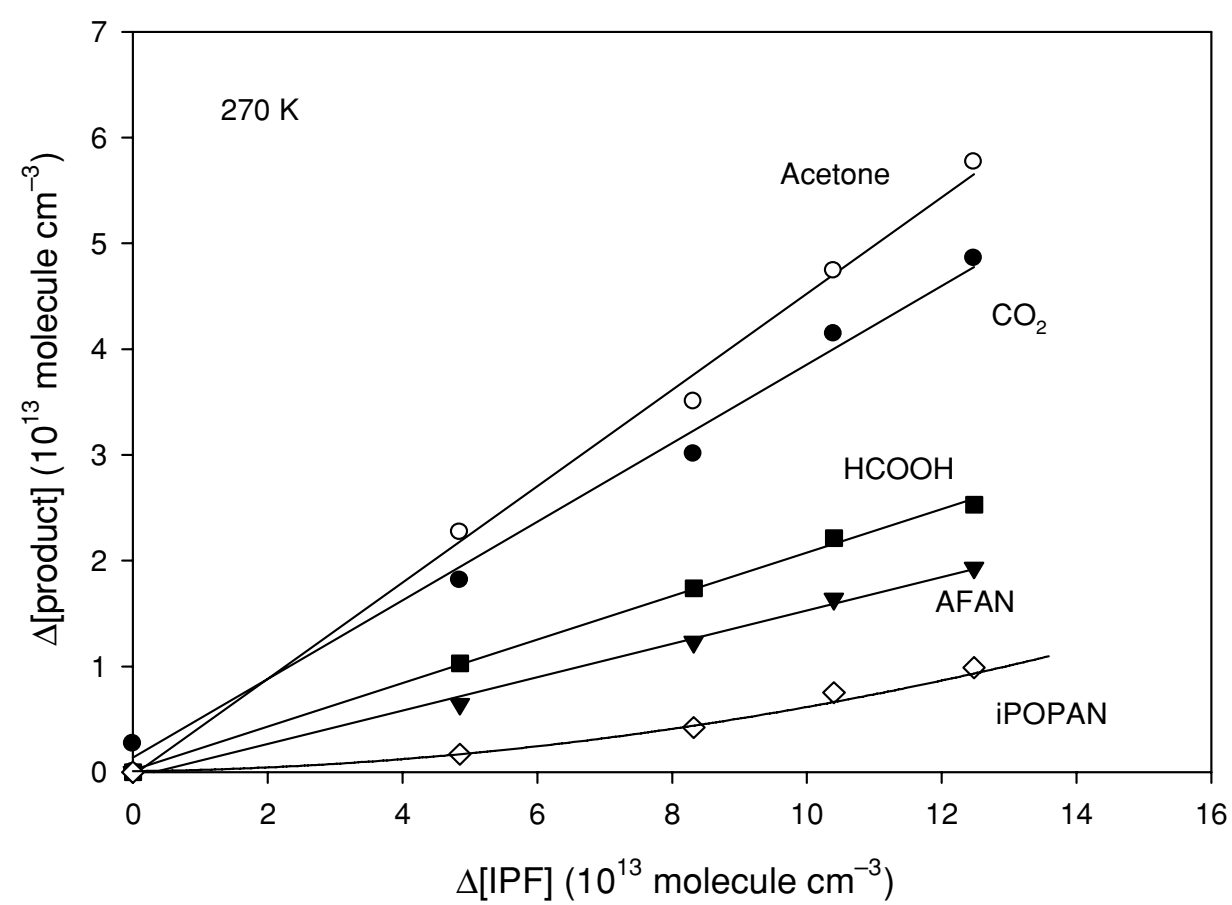

Figure 5 Formation of products from the reaction of $\mathrm{Cl}$ atoms with IPF in the presence of NO $\left(5.4 \times 10^{14} \mathrm{molecule}^{-3}\right)$ and 140 torr $\mathrm{O}_{2}$ (made up to 700 torr with $\mathrm{N}_{2}$ ) at $270 \mathrm{~K}$. $\bullet, \mathrm{CO}_{2}$; O, acetone; $\mathbf{\nabla}, \mathrm{AFAN} ; \mathbf{\square}, \mathrm{HCOOH} ; \diamond$, iPOPAN.

Thus, the yield of iPOPAN is given by

$$
\mathrm{Y}(\mathrm{iPOPAN})=\mathrm{Y}(\text { formyl }) \times \frac{k_{51}\left[\mathrm{NO}_{2}\right]}{k_{51}\left[\mathrm{NO}_{2}\right]+k_{35 a}[\mathrm{NO}]}
$$

or

$$
\frac{\Delta[\mathrm{IPF}]}{\Delta[\mathrm{iPOPAN}]}=\frac{1}{\mathrm{Y}(\text { formyl })} \times\left(1+\frac{k_{35 \mathrm{a}}[\mathrm{NO}]}{k_{51}\left[\mathrm{NO}_{2}\right]}\right)
$$

where $\mathrm{Y}$ (formyl) is the fractional attack of $\mathrm{Cl}$ at the formyl site. The quantity $1 / \mathrm{Y}(\mathrm{iPOPAN})=\Delta(\mathrm{IPF}) /$ $\Delta$ (iPOPAN) was plotted versus $\langle\mathrm{NO}\rangle /\left\langle\mathrm{NO}_{2}\right\rangle$ for individual irradiation steps during a series of experiments, where $\langle\mathrm{NO}\rangle$ represents the mean of the NO concentrations measured before and after each photolysis step (similar for $\mathrm{NO}_{2}$ ). A linear plot was obtained, as shown in Fig. S3 in the Supporting Information, with an intercept $3.1 \pm 0.3$ and a slope of $6.7 \pm 0.5$. The intercept corresponds to the reciprocal of the branching fraction for attack at the formyl group $(32 \pm 3) \%$. The slope is the ratio of rate coefficients $k_{35 a} / k_{51}$ for the acyl peroxy radical, divided by the radical yield. The ratio $k_{35 a} / k_{51}$ thus obtained $(2.1 \pm 0.3)$ is identical to that for PAN $(2.1 \pm 0.2)$ [32].

Experiments conducted at $270 \mathrm{~K}$ in the presence of NO showed considerably reduced yields of AFAN, $15-18 \%$, compared to $30 \%$ at room temperature (see
Fig. 5). At the same time, acetone yields increased to $45 \%$ (iPOPAN + acetone $=50 \%$ ). The yield of $\mathrm{HCOOH}$ at $270 \mathrm{~K}$ was found not to depend strongly on the $\mathrm{O}_{2}$ concentration in the range 20-400 torr. From experiments on ethyl formate carried out at $270 \mathrm{~K}$ in the absence of NO, Orlando and Tyndall found $k_{15} / k_{16}=1.3 \times 10^{19}$ molecule $\mathrm{cm}^{-3}$ [19]. On the basis of these measurements, an $\mathrm{O}_{2}$ dependence would be expected at this temperature. The lack of a dependence of $\mathrm{HCOOH}$ on $\mathrm{O}_{2}$ suggests that the alpha-ester rearrangement is occurring largely from chemically activated alkoxy radicals. Chemically activated processes are well established for alkoxy radicals produced in the exothermic $\mathrm{ROO}^{\bullet}+\mathrm{NO}$ reaction $[11,13,16]$.

A few experiments were also conducted in the absence of NO. At both 296 and $270 \mathrm{~K}$, the yields of acetone and AFAN were found to be (20-25)\%. In these experiments, alkoxy radicals are produced in roughly thermoneutral $\mathrm{ROO}^{\bullet}+\mathrm{ROO}^{\bullet}$ reactions and are not subject to chemical activation. While such experiments are difficult to interpret quantitatively, because of the variety of peroxy radical cross reactions involved, it does appear that thermalized $\mathrm{HC}(\mathrm{O}) \mathrm{OC}\left(\mathrm{CH}_{3}\right)_{2} \mathrm{O}$ radicals result in higher yields of AFAN relative to acetone, and in fact all of the acetone can thus be accounted for by abstraction at the formyl group (30\%). This is in contrast to the experiments containing NO, where the acetone was distinctly larger than the AFAN, especially 
at $270 \mathrm{~K}$. Thus, it is probable that the mechanism of acetone production from $\mathrm{HC}(\mathrm{O}) \mathrm{OC}\left(\mathrm{CH}_{3}\right)_{2} \mathrm{O} \bullet$ involves chemical activation. Further theoretical considerations of the $\mathrm{HC}(\mathrm{O}) \mathrm{OCH}\left(\mathrm{CH}_{3}\right) \mathrm{O}^{\bullet}$ and $\mathrm{HC}(\mathrm{O}) \mathrm{OC}\left(\mathrm{CH}_{3}\right)_{2} \mathrm{O}^{\bullet}$ radicals can be found in the section Theoretical Calculations.

tert-Butyl Formate. Reaction of $\mathrm{Cl}$ atoms with $\mathrm{TBF}$ can occur at two sites, leading to the formation of two peroxy/oxy radicals.

$$
\begin{gathered}
\mathrm{Cl}+\mathrm{HC}(\mathrm{O}) \mathrm{OC}\left(\mathrm{CH}_{3}\right)_{3}\left(+\mathrm{O}_{2}\right) \\
\rightarrow \mathrm{HCl}+\mathrm{O}_{2} \mathrm{C}(\mathrm{O}) \mathrm{OC}\left(\mathrm{CH}_{3}\right)_{3} \\
\mathrm{O}_{2} \mathrm{C}(\mathrm{O}) \mathrm{OC}\left(\mathrm{CH}_{3}\right)_{3}+\mathrm{NO} \\
\rightarrow \mathrm{NO}_{2}+\mathrm{CO}_{2}+{ }^{\bullet} \mathrm{OC}\left(\mathrm{CH}_{3}\right)_{3} \\
\mathrm{Cl}+\mathrm{HC}(\mathrm{O}) \mathrm{OC}\left(\mathrm{CH}_{3}\right)_{3}\left(+\mathrm{O}_{2}\right) \\
\rightarrow \mathrm{HCl}+\mathrm{HC}(\mathrm{O}) \mathrm{OC}\left(\mathrm{CH}_{3}\right)_{2} \mathrm{CH}_{2} \mathrm{O}_{2} \\
\mathrm{HC}(\mathrm{O}) \mathrm{OC}\left(\mathrm{CH}_{3}\right)_{2} \mathrm{CH}_{2} \mathrm{O}_{2}+\mathrm{NO} \\
\rightarrow \mathrm{HC}(\mathrm{O}) \mathrm{OC}\left(\mathrm{CH}_{3}\right)_{2} \mathrm{CH}_{2} \mathrm{O}^{\bullet}+\mathrm{NO}_{2}
\end{gathered}
$$

The observed products were acetone, $\mathrm{HCHO}, \mathrm{CO}$, $\mathrm{CO}_{2}, \mathrm{AFAN}$ and the PAN-type compound tBOPAN, $\left(\mathrm{CH}_{3}\right)_{3} \mathrm{COC}(\mathrm{O}) \mathrm{O}_{2} \mathrm{NO}_{2}$. Formic acid was only observed with very small yields $(<3 \%)$, and it was probably not formed in a primary channel. Yields are summarized in Table III, and the pathways involved in the oxidation of TBF are shown in the upper half of Reaction Scheme 1. In the presence of NO, high yields of $\mathrm{CO}_{2}(65-80 \%)$ were observed along with acetone (35-45\%) and AFAN (7-12\%); see Fig. 6. No discernible dependence on the NO concentration was found. The combined yield of $\mathrm{CO}$ and $\mathrm{HCHO}$ was
45-55\%, independent of $\mathrm{O}_{2}$ concentration. Measurements of $\mathrm{HCHO}$ at short reaction times, or at high TBF, showed that the direct yield of $\mathrm{HCHO}$ is at least $40 \%$. No methyl nitrite or methyl nitrate was observed in the spectra, showing that the yield of $\mathrm{CH}_{3}$ radicals is minor.

It is expected that reaction at the formyl site will lead to the production of $\mathrm{CO}_{2}$ and acetone, or tBOPAN.

$$
\begin{gathered}
\mathrm{O}_{2} \mathrm{C}(\mathrm{O}) \mathrm{OC}\left(\mathrm{CH}_{3}\right)_{3}+\mathrm{NO} \\
\rightarrow \mathrm{NO}_{2}+\cdot \operatorname{OC}(\mathrm{O}) \mathrm{OC}\left(\mathrm{CH}_{3}\right)_{3} \\
\cdot \mathrm{OC}(\mathrm{O}) \mathrm{OC}\left(\mathrm{CH}_{3}\right)_{3} \rightarrow \mathrm{CO}_{2}+\cdot \mathrm{OC}\left(\mathrm{CH}_{3}\right)_{3} \\
\cdot \mathrm{OC}\left(\mathrm{CH}_{3}\right)_{3} \rightarrow \mathrm{CH}_{3}+\mathrm{CH}_{3} \mathrm{C}(\mathrm{O}) \mathrm{CH}_{3} \\
\mathrm{O}_{2} \mathrm{C}(\mathrm{O}) \mathrm{OC}\left(\mathrm{CH}_{3}\right)_{3}+\mathrm{NO}_{2} \\
\rightarrow\left(\mathrm{CH}_{3}\right)_{3} \mathrm{COC}(\mathrm{O}) \mathrm{O}_{2} \mathrm{NO}_{2}
\end{gathered}
$$

However, in chamber experiments, where large amounts of $\mathrm{NO}$ and $\mathrm{NO}_{2}$ are present, the tert-butoxy radical will not decompose, but rather react with $\mathrm{NO}$

\begin{tabular}{|c|c|c|c|c|c|c|c|c|c|}
\hline \multirow[b]{2}{*}{$\begin{array}{l}\mathrm{P}\left(\mathrm{O}_{2}\right) \\
\text { (torr) }\end{array}$} & \multirow[b]{2}{*}{$\begin{array}{c}{[\mathrm{TBF}] \mathrm{o}} \\
\left(\times 10^{14}\right)\end{array}$} & \multirow[b]{2}{*}{$\begin{array}{c}{[\mathrm{NO}] \mathrm{o}} \\
\left(\times 10^{14}\right)\end{array}$} & \multicolumn{7}{|c|}{ Product Yields (\%) } \\
\hline & & & $\mathrm{CO}_{2}$ & $\begin{array}{c}\mathrm{CO}_{2}+ \\
\text { tBOPAN }\end{array}$ & Acetone & $\begin{array}{c}\text { Acetone }+ \\
\text { tBOPAN }\end{array}$ & AFAN & $\begin{array}{c}\mathrm{PAN}+ \\
\mathrm{BuONO}_{x}^{a}\end{array}$ & $\begin{array}{c}\mathrm{CO}+ \\
\mathrm{HCHO}\end{array}$ \\
\hline 450 & 3.5 & 4.7 & 65 & 78 & 31 & 44 & 9 & $26(37)$ & 47 \\
\hline 40 & 3.5 & 5.2 & 78 & 91 & 42 & 55 & 8 & $27(40)$ & 54 \\
\hline $140^{b}$ & 2.4 & 9.8 & 78 & 90 & 43 & 55 & 12 & $26(33)$ & 55 \\
\hline $140^{b}$ & 4.8 & 4.8 & 70 & 88 & 37 & 53 & 12 & $35(43)$ & 39 \\
\hline $140^{b}$ & 4.9 & 9.2 & 65 & 86 & 36 & 57 & 9 & $33(44)$ & 47 \\
\hline $140^{b}$ & 2.4 & 28 & 72 & 84 & 43 & 55 & 7 & $24(32)$ & 46 \\
\hline $10^{b}$ & 2.5 & 9.0 & 78 & 85 & 42 & 49 & 9 & $26(32)$ & 53 \\
\hline $20^{c}$ & 3.5 & 5.6 & 65 & 71 & 46 & 58 & 3 & $23(34)$ & 36 \\
\hline
\end{tabular}
or $\mathrm{NO}_{2}$.

$$
\begin{array}{r}
\cdot \mathrm{OC}\left(\mathrm{CH}_{3}\right)_{3}+\mathrm{NO} \rightarrow\left(\mathrm{CH}_{3}\right)_{3} \mathrm{CONO} \\
\cdot \mathrm{OC}\left(\mathrm{CH}_{3}\right)_{3}+\mathrm{NO}_{2} \rightarrow\left(\mathrm{CH}_{3}\right)_{3} \mathrm{CONO}_{2}
\end{array}
$$

This explains why $\mathrm{CH}_{3}$ radicals are not observed, and the acetone yield is lower than that of $\mathrm{CO}_{2}$. The yields of tert-butyl nitrite and nitrate were not linear, as a result of the varying $\mathrm{NO} / \mathrm{NO}_{2}$ ratio in the chamber. The combined yield of tert-butyl nitrite, tert-butyl nitrate, and tBOPAN was $(37 \pm 5) \%$, which is somewhat lower than the branching ratio found earlier for abstraction at the formyl group.

Table III Experimental Conditions and Product Yields for the Reaction of TBF with $\mathrm{Cl}$ Atoms in the Presence of NO

${ }^{a}$ First entry is for tBOPAN; second includes t-BuONO and t-BuONO${ }_{2}$.

${ }^{b}$ Ford expt.

${ }^{c}$ Expt. at $270 \mathrm{~K}$. 


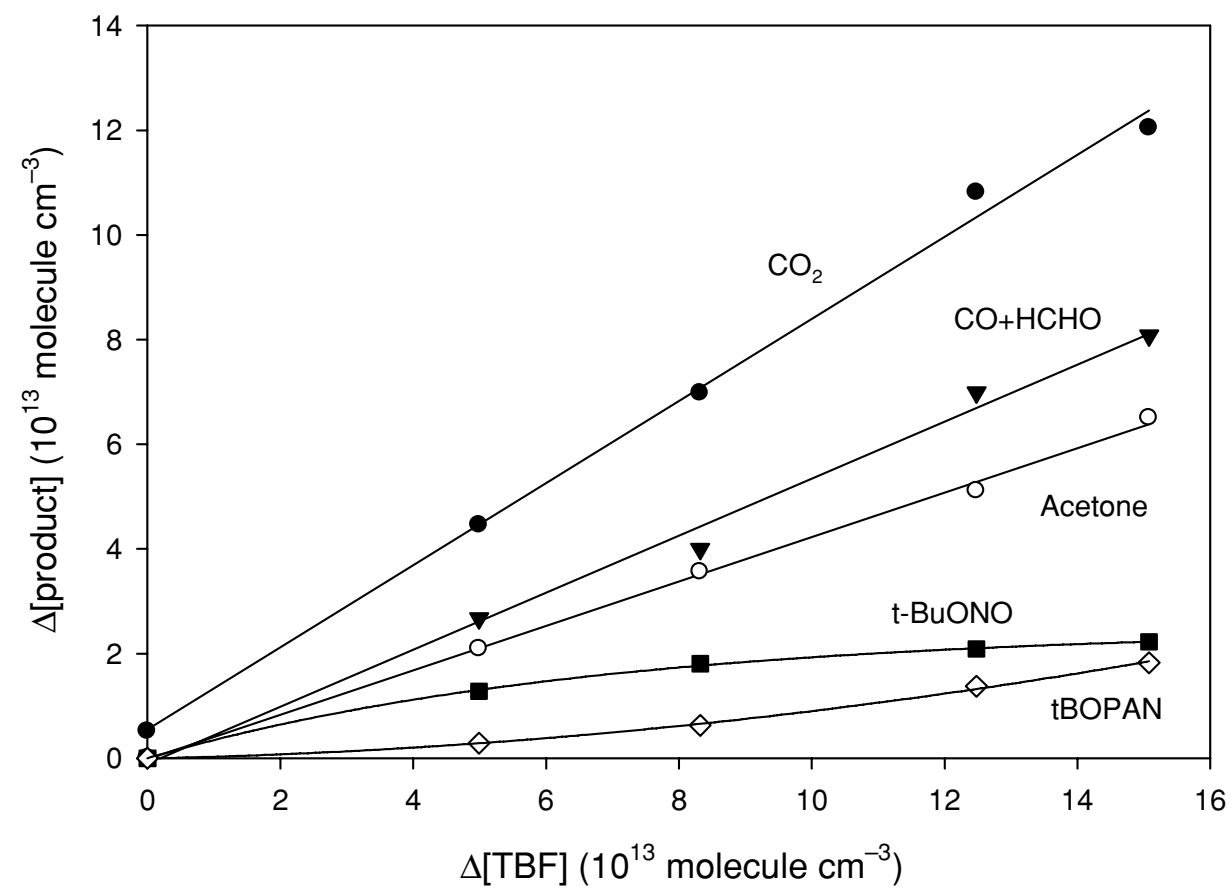

Figure 6 Formation of products from the reaction of $\mathrm{Cl}$ atoms with $\mathrm{TBF}$ in the presence of NO $\left(5.2 \times 10^{14}\right.$ molecule $\left.\mathrm{cm}^{-3}\right)$ and 40 torr $\mathrm{O}_{2}$ (made up to 700 torr with $\mathrm{N}_{2}$ ) at $296 \mathrm{~K}$. $\bullet, \mathrm{CO}_{2} ;$ O, acetone; $\boldsymbol{\nabla}, \mathrm{CO}+\mathrm{HCHO} ; \boldsymbol{\square}$, tert-BuONO; $\diamond$, tBOPAN.

Plots of $\Delta(\mathrm{TBF}) / \Delta(\mathrm{tBOPAN})$ versus $\langle\mathrm{NO}\rangle /\left\langle\mathrm{NO}_{2}\right\rangle$ were made, as in the IPF experiments, to determine the rate coefficient ratio for reaction of tert-butoxy formylperoxy radicals with $\mathrm{NO}(55 \mathrm{a})$ and $\mathrm{NO}_{2}(58)$. The intercept corresponded to a yield of $42 \%$ for acyl radicals, while the slope gave a ratio of rate coefficients $k_{55 \mathrm{a}} / k_{58}=1.7 \pm 0.4$, in good agreement with the isopropyl system.

Abstraction of one of the primary hydrogen atoms leads to the $\mathrm{HC}(\mathrm{O}) \mathrm{OC}\left(\mathrm{CH}_{3}\right)_{2} \mathrm{CH}_{2} \mathrm{O}_{2}$ radical, which reacts with $\mathrm{NO}$ to form the alkoxy radical $\mathrm{HC}(\mathrm{O}) \mathrm{OC}\left(\mathrm{CH}_{3}\right)_{2} \mathrm{CH}_{2} \mathrm{O}^{\bullet}$. Three possible reactions are likely for this radical: decomposition, reaction with $\mathrm{O}_{2}$, or isomerization via a six-membered transition state.

$$
\begin{aligned}
& \mathrm{HC}(\mathrm{O}) \mathrm{OC}\left(\mathrm{CH}_{3}\right)_{2} \mathrm{CH}_{2} \mathrm{O}^{\bullet} \\
& \quad \rightarrow \mathrm{HCHO}+\mathrm{HC}(\mathrm{O}) \mathrm{OC} \cdot\left(\mathrm{CH}_{3}\right)_{2} \\
& \mathrm{HC}(\mathrm{O}) \mathrm{OC}\left(\mathrm{CH}_{3}\right)_{2} \mathrm{CH}_{2} \mathrm{O}^{\bullet}+\mathrm{O}_{2} \\
& \quad \rightarrow \mathrm{HO}_{2}+\mathrm{HC}(\mathrm{O}) \mathrm{OC}\left(\mathrm{CH}_{3}\right)_{2} \mathrm{CHO} \\
& \mathrm{HC}(\mathrm{O}) \mathrm{OC}\left(\mathrm{CH}_{3}\right)_{2} \mathrm{CH}_{2} \mathrm{O}^{\bullet} \\
& \quad \rightarrow{ }^{\bullet} \mathrm{C}(\mathrm{O}) \mathrm{OC}^{-}\left(\mathrm{CH}_{3}\right)_{2} \mathrm{CH}_{2} \mathrm{OH} \\
& \cdot \mathrm{C}(\mathrm{O}) \mathrm{OC}\left(\mathrm{CH}_{3}\right)_{2} \mathrm{CH}_{2} \mathrm{OH}\left(+\mathrm{O}_{2}, \mathrm{NO}\right) \\
& \quad \rightarrow \mathrm{CO}_{2}+\mathrm{CH}_{3} \mathrm{C}(\mathrm{O}) \mathrm{CH}_{3}+\mathrm{HCHO}
\end{aligned}
$$

By analogy with oxy radicals derived from substituted ethers [34], and the corresponding radical derived from IPF, reaction with $\mathrm{O}_{2}(62)$ is not expected to compete with the two other channels. Picquet-Varrault et al. studied the oxidation of a series of acetates and looked for evidence of the production of $\beta$-acetoxy carbonyls analogous to the products of reaction $(62)[14,15]$. Such compounds were identified only when they could be formed from decomposition of a larger oxy radical, not from reaction of a primary radical with $\mathrm{O}_{2}$.

The radical formed in reaction $(61), \mathrm{HC}(\mathrm{O}) \mathrm{OC}^{\bullet}$ $\left(\mathrm{CH}_{3}\right)_{2}$, is identical to that formed from abstraction at the tertiary site in IPF. However, that radical was shown in the preceding section to give roughly $50 \%$ more AFAN than acetone, contrary to what is observed in the case of TBF. A small yield of AFAN is observed $(9 \pm 3 \%)$, which could come from decomposition of $\mathrm{HC}(\mathrm{O}) \mathrm{OC}\left(\mathrm{CH}_{3}\right)_{2} \mathrm{CH}_{2} \mathrm{O}^{\bullet}$. It appears that the primary alkoxy radical $\mathrm{HC}(\mathrm{O}) \mathrm{OC}\left(\mathrm{CH}_{3}\right)_{2} \mathrm{CH}_{2} \mathrm{O}^{\bullet}$ predominantly isomerizes via reaction (63), to eventually give $\mathrm{CO}_{2}, \mathrm{HCHO}$, and acetone, and that this accounts for most of the acetone observed in these experiments. The alkoxy carbonyl radicals formed from the isomerization reaction are probably chemically activated and possess enough energy to decompose spontaneously by elimination of $\mathrm{CO}_{2}$, rather than adding $\mathrm{O}_{2}$.

$$
\begin{aligned}
& \cdot \mathrm{C}(\mathrm{O}) \mathrm{OC}\left(\mathrm{CH}_{3}\right)_{2} \mathrm{CH}_{2} \mathrm{OH} \\
& \quad \rightarrow \mathrm{CO}_{2}+{ }^{\cdot} \mathrm{C}_{(}\left(\mathrm{CH}_{3}\right)_{2} \mathrm{CH}_{2} \mathrm{OH}
\end{aligned}
$$


This behavior is in contrast to the isopropyl case, where the alkoxy radical formed from the primary methyl groups was found to eliminate $\mathrm{HCHO}$. The reason for this difference is unknown. It is probable that the decomposition and isomerization channels are active to some extent in both molecules (see results of theoretical calculations later); however, the existence of multiple pathways to acetone precludes any more quantitative analysis. Experiments at $270 \mathrm{~K}$ and in the absence of NO at $296 \mathrm{~K}$ led largely to the same product distribution as described above.

\section{Reactions of IPF and TBF with OH Radicals}

In the atmosphere, the oxidation of these esters will be initiated predominantly by reaction with $\mathrm{OH}$ radicals, and so a limited number of experiments was performed to investigate the reaction mechanisms with $\mathrm{OH}$. Both methyl and ethyl nitrites were used as photolytic sources of $\mathrm{OH}$.

In the case of IPF, the same set of products was formed as with $\mathrm{Cl}$-initiated oxidation, although quantitative differences were found in the product distribution (see Fig. 7). The observed yields were AFAN $(43 \%)$, acetone $(43 \%)$, and $\mathrm{HCOOH}(15-20 \%)$. The higher yield of AFAN is consistent with more abstraction at the tertiary site (55-65\%), compared to the chlorine atom reaction. At long reaction times, as the ratio $\mathrm{NO}_{2} / \mathrm{NO}$ increased, the yield of iPOPAN approached
$20-25 \%$, suggesting that the yield of abstraction at the $\mathrm{H}-\mathrm{C}(\mathrm{O})$ group is similar to the chlorine experiments. The product yields given above should correspond closely with those found in the atmosphere, where oxidation is largely initiated by $\mathrm{OH}$ radicals.

It is expected that $\mathrm{OH}$ radicals are produced in the $\mathrm{Cl}$-atom studies following generation of $\mathrm{HO}_{2}$.

$$
\begin{gathered}
\mathrm{HO}_{2}+\mathrm{NO} \rightarrow \mathrm{OH}+\mathrm{NO}_{2} \\
\mathrm{OH}+\mathrm{IPF} \rightarrow \text { product }
\end{gathered}
$$

Simulations of the chemical mechanism using the Acuchem program [37] indicated that for the $\mathrm{Cl}$-atom experiments, up to $30 \%$ of the attack on IPF could be from $\mathrm{OH}$ radicals, necessitating a revision of the product yields from $\mathrm{Cl}$-atom attack. The preferred values are then: reaction at the formyl group, $(30 \pm 5) \%$, reaction at the methyl groups, $(20 \pm 5) \%$ leading to $\mathrm{HCOOH}$, and reaction at the tertiary carbon, $(50 \pm$ 5)\% leading to 30\% AFAN and (15-20)\% acetone. The branching ratios for $\mathrm{OH}$ reaction, which are relevant to the atmosphere, remain the same as measured here.

When TBF was oxidized by $\mathrm{OH}$, the yields were essentially identical to the $\mathrm{Cl}$-initiated oxidation, i.e., AFAN $<10 \%$, acetone $\sim 40 \%$, acetone + tert -BuONO + tert- $\mathrm{BuONO}_{2} \sim \mathrm{CO}_{2} \sim 70 \%$. Hence, the OHinitiated oxidation of TBF also proceeds by roughly

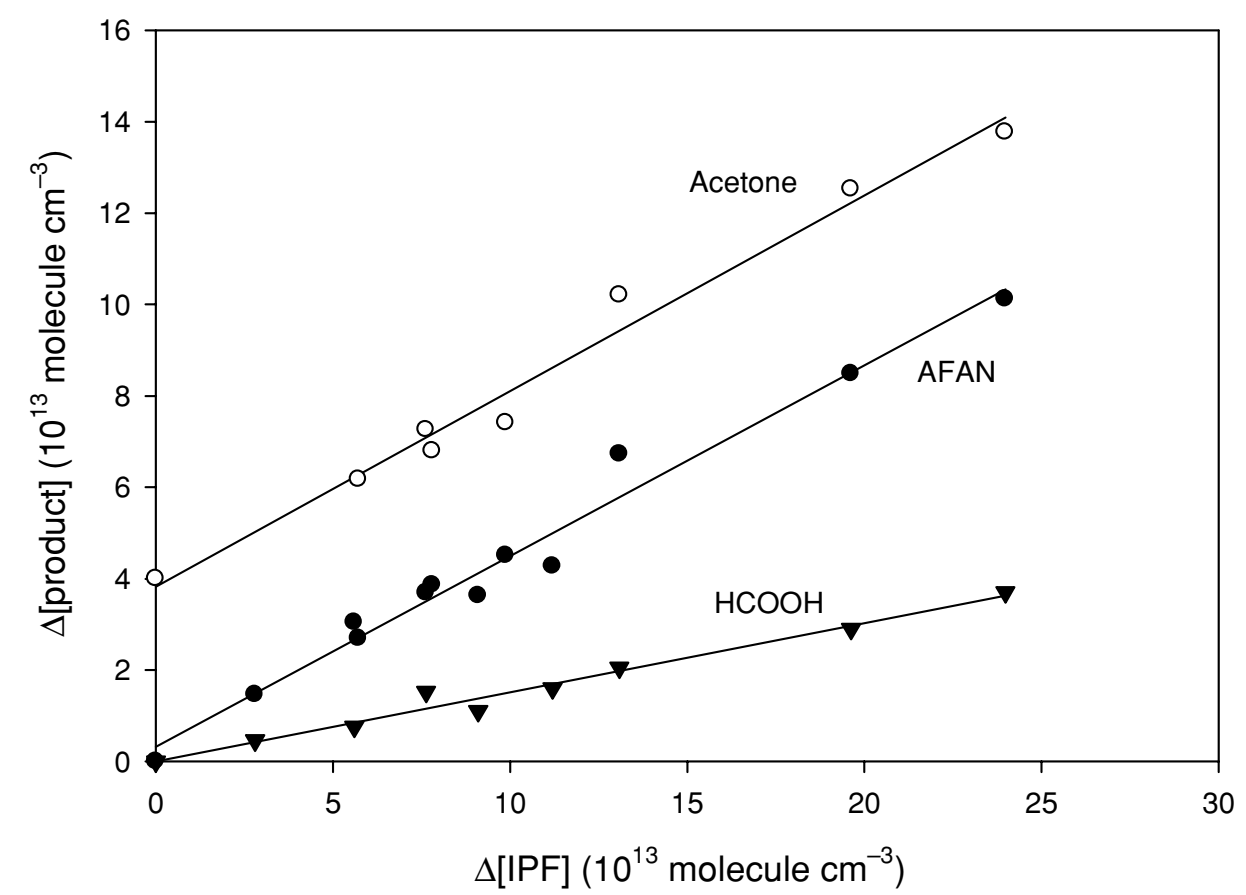

Figure 7 Formation of products from the reaction of $\mathrm{OH}$ radicals with IPF in air $\left(140\right.$ torr $\mathrm{O}_{2}+560$ torr $\left.\mathrm{N}_{2}\right)$ at $296 \mathrm{~K}$. 
equal abstraction at the formyl and primary sites. At long reaction times, formation of $\mathrm{tBOPAN}$ was found, confirming a substantial fraction of attack at the formyl group. The slow rate of reaction of $\mathrm{OH}$ with TBF $[28,38]$, and low yields of AFAN, made more quantitative description difficult. In the atmosphere, where tert-butoxy radicals decompose rather than react with $\mathrm{NO}$ or $\mathrm{NO}_{2}$, the major product will be acetone with a yield $>80 \%$, regardless of the site of attack.

\section{THEORETICAL CALCULATIONS}

To interpret the experimental results, quantum chemical calculations were carried out to determine the structures and energies of some of the transition states in the IPF system. The alkyl and alkylperoxy radicals are expected to follow well-documented reactions. However, the behavior of the oxy radicals cannot be predicted easily. Calculations were carried out for the two initially formed oxy radicals, $\mathrm{HC}(\mathrm{O}) \mathrm{OCH}\left(\mathrm{CH}_{3}\right) \mathrm{CH}_{2} \mathrm{O}^{\bullet}$ and $\mathrm{HC}(\mathrm{O}) \mathrm{OC}\left(\mathrm{CH}_{3}\right)_{2} \mathrm{O}^{\bullet}$, and for the radical formed by decomposition of the alkoxy radical formed by abstraction at the primary site, $\mathrm{HC}(\mathrm{O}) \mathrm{OCH}\left(\mathrm{CH}_{3}\right) \mathrm{O}^{\bullet}$. The reactions considered were decomposition, isomerization, and the alpha-ester rearrangement (for the latter).

Stationary points on the potential energy surfaces for decomposition pathways of the alkoxy radicals were characterized via the CBS-QB3 approach of Petersson and co-workers [39], as implemented in the Gaussian 03 program [40]. Geometries and frequencies, scaled by a standard factor of 0.99 [39], were computed with the B3LYP/6-311G(d,p) level of theory. Next, the energies were derived via coupled cluster $(\mathrm{CCSD}(\mathrm{T}))$ theory with approximate extrapolation to the complete basis set limit. For stable molecules, this approach yields atomization energies with a mean absolute deviation of $0.6 \mathrm{kcal} \mathrm{mol}^{-1}$ from experiment. Rate constants for unimolecular decomposition at the high-pressure limit were derived via conventional transition state theory [41]. The reaction rate constants should be close to the high-pressure limiting values under the experimental conditions. In the cases of $\mathrm{H}$-atom transfer or elimination pathways, a Wigner tunneling correction was included [42]. This is not expected to be accurate when tunneling is large, but for the present reactions it indicated that at room temperature tunneling increased the reaction rate by only about a factor of 2 . The calculated rate constants were well-described by the Arrhenius equation between 200 and $400 \mathrm{~K}$, and the results of the calculations are shown in Table IV.

For the primary $\mathrm{HC}(\mathrm{O}) \mathrm{OCH}\left(\mathrm{CH}_{3}\right) \mathrm{CH}_{2} \mathrm{O}^{\bullet}$ radical from IPF, isomerization was calculated to be facile, $\sim 10^{9} \mathrm{~s}^{-1}$, and to dominate over decomposition by loss of $\mathrm{HCHO}$.

$$
\begin{aligned}
& \mathrm{HC}(\mathrm{O}) \mathrm{OCH}\left(\mathrm{CH}_{3}\right) \mathrm{CH}_{2} \mathrm{O}^{\bullet} \\
& \quad \rightarrow{ }^{\bullet} \mathrm{C}(\mathrm{O}) \mathrm{OCH}\left(\mathrm{CH}_{3}\right) \mathrm{CH}_{2} \mathrm{OH} \\
& \mathrm{HC}(\mathrm{O}) \mathrm{OCH}\left(\mathrm{CH}_{3}\right) \mathrm{CH}_{2} \mathrm{O}^{\bullet} \\
& \rightarrow \mathrm{HCHO}+\mathrm{HC}(\mathrm{O}) \mathrm{OC}^{\bullet} \mathrm{H}_{\left(\mathrm{CH}_{3}\right)}
\end{aligned}
$$

The calculated decomposition rate, $\sim 10^{6} \mathrm{~s}^{-1}$, is very similar to those estimated by Aschmann and Atkinson [34] for analogous radicals formed in ether oxidation. The experimental observations presented here suggest that the radical decomposes and that the calculated activation energy for the isomerization may be too low.

\begin{tabular}{|c|c|c|c|c|}
\hline Radical/Reaction & Barrier at $0 \mathrm{~K}\left(\mathrm{kcal} \mathrm{mol}^{-1}\right)$ & $A\left(\mathrm{~s}^{-1}\right)$ & $E_{a}\left(\mathrm{kcal} \mathrm{mol}^{-1}\right)$ & $k_{298}\left(\mathrm{~s}^{-1}\right)$ \\
\hline \multicolumn{5}{|c|}{$\mathrm{HC}(\mathrm{O}) \mathrm{OCH}\left(\mathrm{CH}_{3}\right) \mathrm{CH}_{2} \mathrm{O}^{\bullet}$} \\
\hline HCHO loss & 9.4 & $5.2 \mathrm{E} 13$ & 10.2 & $1.7 \mathrm{E} 6$ \\
\hline Isomerization & 4.7 & $1.1 \mathrm{E} 12$ & 4.2 & $9.8 \mathrm{E} 8$ \\
\hline \multicolumn{5}{|c|}{$\mathrm{HC}(\mathrm{O}) \mathrm{OC}\left(\mathrm{CH}_{3}\right)_{2} \mathrm{O}^{\bullet}$} \\
\hline $\mathrm{CH}_{3}$ loss & 9.4 & $1.8 \mathrm{E} 14$ & 10.2 & $5.6 \mathrm{E} 6$ \\
\hline $\mathrm{HCO}_{2}$ loss & 14.3 & $1.9 \mathrm{E} 13$ & 14.9 & 220 \\
\hline Isomerization & 10.8 & $2.8 \mathrm{e} 12$ & 10.3 & 7.7E4 \\
\hline \multicolumn{5}{|c|}{$\mathrm{HC}(\mathrm{O}) \mathrm{OCH}\left(\mathrm{CH}_{3}\right) \mathrm{O}^{\bullet a}$} \\
\hline $\mathrm{HCO}_{2}$ loss & $25.5 / 21.0$ & $5.0 \mathrm{E} 13$ & $26.2 / 21.7$ & $2.3 \mathrm{E}-6 / 5.6 \mathrm{E}-3$ \\
\hline Isomerization & $15.8 / 11.2$ & $3.4 \mathrm{E} 12$ & $15.4 / 10.8$ & $16 / 3.8 \mathrm{E} 4$ \\
\hline$\alpha$-ester & $11.9 / 7.3$ & 8.9E12 & $12.3 / 7.7$ & 4.6E3/2.1E7 \\
\hline $\mathrm{H}$ loss & $17.5 / 12.9$ & $2.2 \mathrm{E} 13$ & $17.6 / 13.0$ & 2.3/5.7E3 \\
\hline $\mathrm{CH}_{3}$ loss & $13.0 / 14.4$ & $8.9 \mathrm{E} 13$ & $13.6 / 15.2$ & $1.3 \mathrm{E} 4 / 5.8 \mathrm{E} 2$ \\
\hline
\end{tabular}

For the $\mathrm{HC}(\mathrm{O}) \mathrm{OC}\left(\mathrm{CH}_{3}\right)_{2} \mathrm{O}^{\bullet}$ radical, loss of a methyl group (42) is calculated to be more rapid than the

Table IV Calculated Unimolecular Reaction Rates at the High Pressure Limit for Oxy Radicals

\footnotetext{
${ }^{a}$ First numbers refer to more stable conformer, A, second numbers to less stable conformer, B.
} 
isomerization channel via a five-membered transition state (44), with computed rate coefficients of $\sim 10^{6}$ and $\sim 10^{5} \mathrm{~s}^{-1}$, respectively. The difference arises largely because isomerization via the ring is entropically unfavorable and has a pre-exponential factor $\sim 10^{2}$ times smaller than for $\mathrm{C}-\mathrm{C}$ bond cleavage.

$$
\mathrm{HC}(\mathrm{O}) \mathrm{OC}\left(\mathrm{CH}_{3}\right)_{2} \mathrm{O}^{\bullet} \rightarrow \mathrm{HC}(\mathrm{O}) \mathrm{OC}(\mathrm{O}) \mathrm{CH}_{3}+\mathrm{CH}_{3}
$$

$$
\begin{aligned}
& \mathrm{HC}(\mathrm{O}) \mathrm{OC}\left(\mathrm{CH}_{3}\right)_{2} \mathrm{O}^{\bullet} \\
& \quad \rightarrow{ }^{\bullet} \mathrm{C}(\mathrm{O}) \mathrm{OC}\left(\mathrm{CH}_{3}\right)_{2} \mathrm{OH} \rightarrow \rightarrow \text { acetone }
\end{aligned}
$$

Cleavage of the $\mathrm{C}(\mathrm{O})-\mathrm{O}$ bond was calculated to be much slower, $\sim 10^{2} \mathrm{~s}^{-1}$, as predicted by Aschmann and Atkinson [34] and Good and Francisco [35] for similar species.

$$
\mathrm{HC}(\mathrm{O}) \mathrm{OC}\left(\mathrm{CH}_{3}\right)_{2} \mathrm{O}^{\bullet} \rightarrow \mathrm{HC}(\mathrm{O}) \mathrm{O}+\mathrm{CH}_{3} \mathrm{C}(\mathrm{O}) \mathrm{CH}_{3}
$$

Calculations were also carried out at a lower level of theory B3LYP/6-311G(2df,2p). The barriers for reactions (42), (44), and (47) were calculated to be 11.3, 10.2 and $12.9 \mathrm{kcal} \mathrm{mol}^{-1}$, respectively, in very good agreement with those at the higher level (shown in Table IV). It is reassuring that such good agreement can be obtained with a lower level of theory.

Experimentally, we observed the yield of AFAN from this radical to be approximately three times greater than the yield of acetone. Experiments without NO present showed production of AFAN from this radical to dominate over acetone at both 296 and $270 \mathrm{~K}$. The observations imply that the production of acetone from the tertiary radical is mediated through chemically activated radicals, either by isomerization or from the loss of $\mathrm{HC}(\mathrm{O}) \mathrm{O}$. This suggests that the barrier for the channel leading to acetone production is smaller than that leading to AFAN, allowing for preferential activation of that channel.

The final radical to be studied, $\mathrm{HC}(\mathrm{O}) \mathrm{OCH}$ $\left(\mathrm{CH}_{3}\right) \mathrm{O}^{\bullet}$, is interesting in that it has two relatively stable configurations separated by a few $\mathrm{kcal} \mathrm{mol}^{-1}$ : one (A) in which the carbonyl oxygen is hydrogen bonded to the hydrogen atom adjacent to the ether linkage, and one (B) in which the oxygen atom bearing the unpaired electron is hydrogen bonded to the formyl $\mathrm{H}$ atom. The calculations show that (A) is the more stable conformer by $4.6 \mathrm{kcal} \mathrm{mol}^{-1}$, with a barrier to interconversion of $7.4 \mathrm{kcal} \mathrm{mol}^{-1}$, which leads at $298 \mathrm{~K}$ to a rate of interconversion $\mathrm{A} \rightarrow \mathrm{B}$ of $4 \times 10^{6} \mathrm{~s}^{-1}$ and $\mathrm{B} \rightarrow \mathrm{A}$ of $9 \times 10^{9} \mathrm{~s}^{-1}$. These rates should be suffi- ciently rapid that thermal equilibrium is maintained between the conformers. Hence, the overall reaction rate should correspond to a weighted sum of the two conformers. The calculated loss rate of $-\mathrm{CH}_{3}$ radicals (50) is $10^{3}-10^{4} \mathrm{~s}^{-1}$ from either conformer. The alpha ester rearrangement (15) is calculated to have rates of $4600 \mathrm{~s}^{-1}$ from conformer (A) and $2 \times 10^{7} \mathrm{~s}^{-1}$ from (B).

$$
\begin{aligned}
& \mathrm{HC}(\mathrm{O}) \mathrm{OCH}\left(\mathrm{CH}_{3}\right) \mathrm{O}^{\bullet} \rightarrow \mathrm{HC}(\mathrm{O}) \mathrm{OCHO}+\mathrm{CH}_{3} \\
& \mathrm{HC}(\mathrm{O}) \mathrm{OCH}\left(\mathrm{CH}_{3}\right) \mathrm{O}^{\bullet} \rightarrow \mathrm{HC}(\mathrm{O}) \mathrm{OH}+\mathrm{CH}_{3} \mathrm{CO}
\end{aligned}
$$

Transition states for these two reaction pathways are shown in Fig. 8, and Fig. 9 shows an Arrhenius plot of all the possible unimolecular pathways from this radical. The experimental evidence [19] shows that the rate coefficient for the alpha-ester rearrangement (15) is of the order $5 \times 10^{5} \mathrm{~s}^{-1}$, with a barrier of 8-9 kcal $\mathrm{mol}^{-1}$, intermediate between those calculated for conformers (A) and (B). Raising the energy of conformer (A) relative to both conformer (B) and the transition state by around $2 \mathrm{kcal} \mathrm{mol}^{-1}$ would largely take away the discrepancy. No experimental evidence was found for formic anhydride produced in reaction (50), although Picquet-Varrault et al. [15] found evidence for

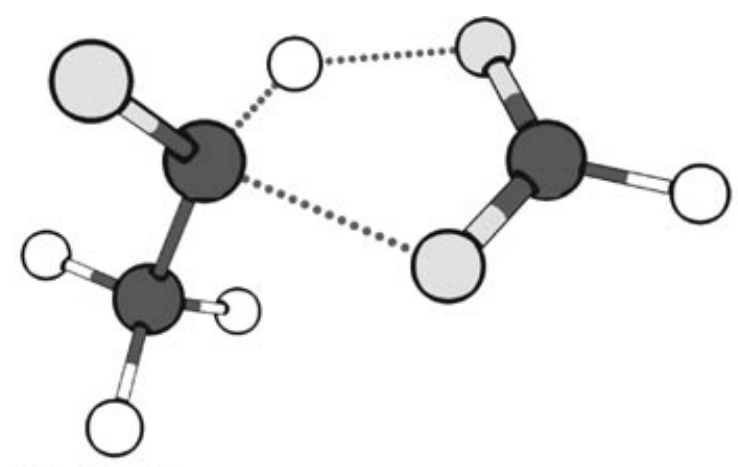

(a) $\alpha$ ester TS

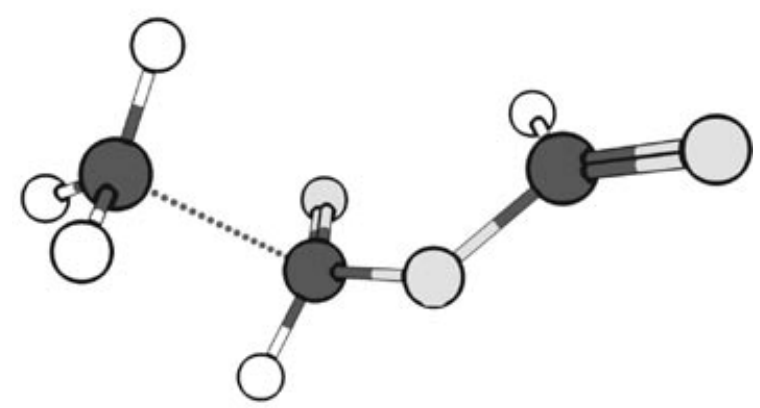

(b) $\mathrm{CH}_{3}$ loss TS

Figure 8 Transition states for the $\alpha$-ester rearrangement and for loss of a methyl group from the $\mathrm{HC}(\mathrm{O}) \mathrm{OCH}\left(\mathrm{CH}_{3}\right) \mathrm{O}^{\bullet}$ radical. 


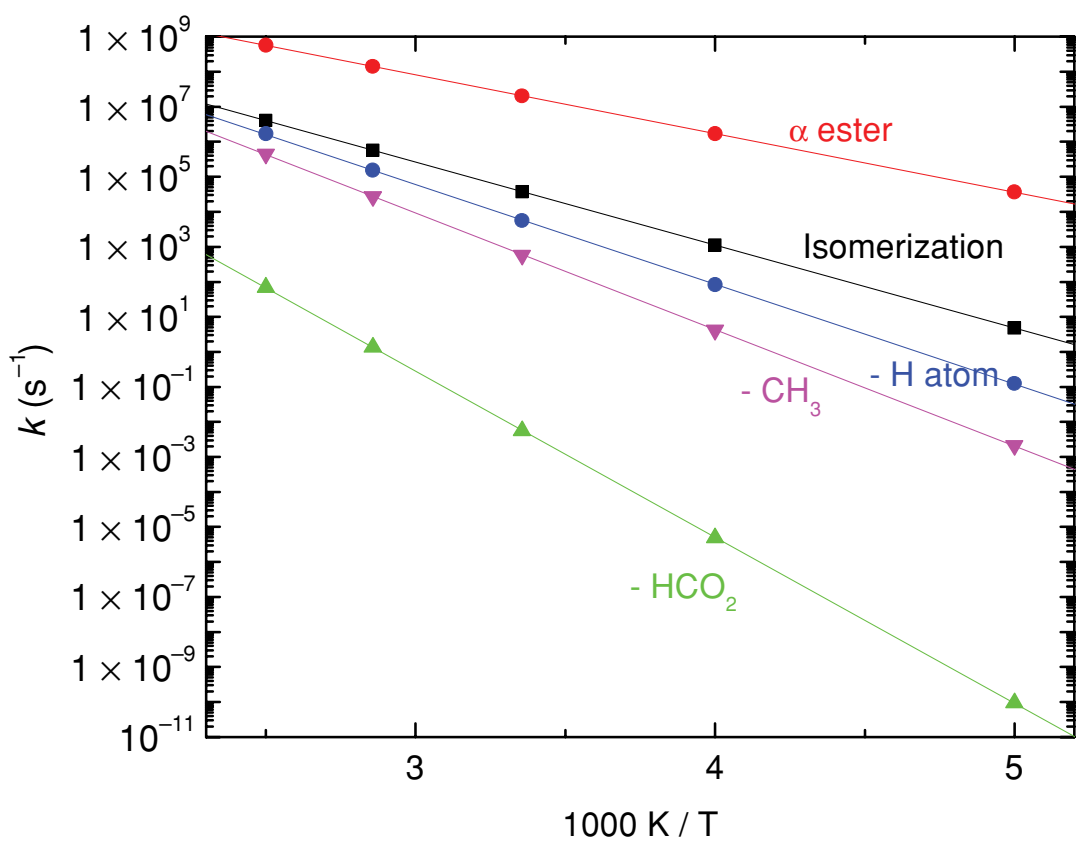

Figure 9 Arrhenius plot showing the rates of the different unimolecular reaction pathways for the $\mathrm{HC}(\mathrm{O}) \mathrm{OCH}\left(\mathrm{CH}_{3}\right) \mathrm{O}^{\bullet}$ radical. [Color figure can be viewed in the online issue, which is available at www.interscience.wiley.com.]

decomposition of the analogous radical from isobutyl acetate.

The transition state for the alpha-ester rearrangement is difficult to calculate, since it involves the simultaneous breaking of two bonds and shifts of the carbonyl electrons from one oxygen atom to the other $[17,18]$. However, the present calculations indicate that the decomposition rates are similar in magnitude to those observed and that the decomposition and rearrangement reactions should be competitive, even if the exact ordering of reaction channels is difficult to reproduce. The dynamics of the reactions is undoubtedly complicated by the presence of internal hydrogen bonds in the radicals, which affect both the thermochemistry and the stereochemistry of the reactions.

\section{DISCUSSION}

The studies described in the preceding sections show that the major products from the oxidation of IPF in the presence of $\mathrm{NO}$ are acetone, AFAN, and formic acid, along with $\mathrm{CO}, \mathrm{CO}_{2}$, and formaldehyde. It is difficult to assign an unambiguous reaction mechanism, since each of the radicals can react by more than one channel, and each product can be formed by more than one pathway. Furthermore, none of the pathways is strongly dependent on the oxygen partial pressure (and in fact any weak $\mathrm{O}_{2}$ dependences observed are probably a result of changes in the $\mathrm{NO} / \mathrm{NO}_{2}$ ratio). However, significant insight into the mechanism can be gained based on the knowledge of the reaction branching fractions and from the behavior of the product yields as a function of temperature.

Formic acid was observed from the oxidation of IPF for all experiments, regardless of temperature or oxygen partial pressure. While it is expected that its production results from the alpha-ester rearrangement of $\mathrm{HC}(\mathrm{O}) \mathrm{OCH}\left(\mathrm{CH}_{3}\right) \mathrm{O}^{\bullet}$, it is possible that there exists a further, unidentified channel leading to $\mathrm{HCOOH}$ production.

At room temperature, it appears that decomposition of the $\mathrm{HC}(\mathrm{O}) \mathrm{OC}\left(\mathrm{CH}_{3}\right)_{2} \mathrm{O}^{\bullet}$ radical results in the formation of AFAN (by methyl elimination), which dominates over acetone formation (probably by isomerization). This can be understood by virtue of the fact that decomposition reactions normally have a large Afactor and large activation barrier, whereas isomerization reactions have both a smaller A-factor and smaller barrier [43]. Furthermore, the experiments without NO present showed roughly equal yields of AFAN and acetone at room temperature. These observations together imply that the production of acetone from the tertiary radical is mediated through chemically activated radicals. Simple bond additivity calculations give an enthalpy of decomposition for $\mathrm{HC}(\mathrm{O}) \mathrm{OC}\left(\mathrm{CH}_{3}\right)_{2} \mathrm{O}^{\bullet}$ of $0 \pm 2 \mathrm{kcal} \mathrm{mol}^{-1}$, whereas that for $\mathrm{CH}_{3} \mathrm{OC}\left(\mathrm{CH}_{3}\right)_{2} \mathrm{O}^{\bullet}$ is $-5 \pm 2 \mathrm{kcal} \mathrm{mol}^{-1}$. Hence the driving force going from ether to ester is stronger than that from ester to anhydride, and as a consequence, the decomposition 
reactions do not dominate as much as they do for ethers [34,43].

An interesting aspect of these mechanisms is the production of activated alkoxy radicals from the reaction at the formyl site. Reactions of acyl peroxy radicals with NO are generally quite exothermic ( $\sim 20 \mathrm{kcal} \mathrm{mol}^{-1}$ ) and lead to the formation of unstable acyloxy radicals, which decompose very rapidly. The overall exothermicity of the reaction sequence represented by (68) could be as much as $30 \mathrm{kcal} \mathrm{mol}^{-1}$ [22].

$$
\begin{aligned}
& \mathrm{O}_{2} \mathrm{C}(\mathrm{O}) \mathrm{OC}\left(\mathrm{CH}_{3}\right)_{2} \mathrm{R}+\mathrm{NO} \\
& \quad \rightarrow \mathrm{NO}_{2}+\mathrm{CO}_{2}+\left[\left(\mathrm{CH}_{3}\right)_{2} \mathrm{RCO}^{\bullet}\right]^{\ddagger}
\end{aligned}
$$

Although a small barrier is predicted for the decomposition of $\mathrm{ROCO}_{2}$ radicals [35], under conditions of chemical activation their decomposition should be facile. Depending on how the energy is disposed, the resulting isopropoxy or tert-butoxy radicals could have sufficient energy to decompose spontaneously (barriers 15.5 and $14.3 \mathrm{kcal} \mathrm{mol}^{-1}$, respectively [43]).

$$
\left[\left(\mathrm{CH}_{3}\right)_{2} \mathrm{RCO}^{\bullet}\right]^{\ddagger} \rightarrow \mathrm{CH}_{3}+\mathrm{CH}_{3} \mathrm{C}(\mathrm{O}) \mathrm{R}
$$

There was some evidence for prompt decomposition of the alkoxy radicals. For example, in experiments where NO was added to the tBOPAN, formation of acetone was observed with a yield of $30 \%$ per tBOPAN decomposed. While not totally quantitative, these experiments suggest that as much as one third of the tert-butoxy radicals are formed with sufficient energy to decompose before being trapped by NO or $\mathrm{NO}_{2}$. Normally, chemical activation of alkoxy radicals produced from the reaction of $\mathrm{NO}$ with $\mathrm{RO}_{2}$ radicals is only observed when the barriers to decomposition are relatively low. The requirement for a low barrier limits the effects of chemical activation to substituted

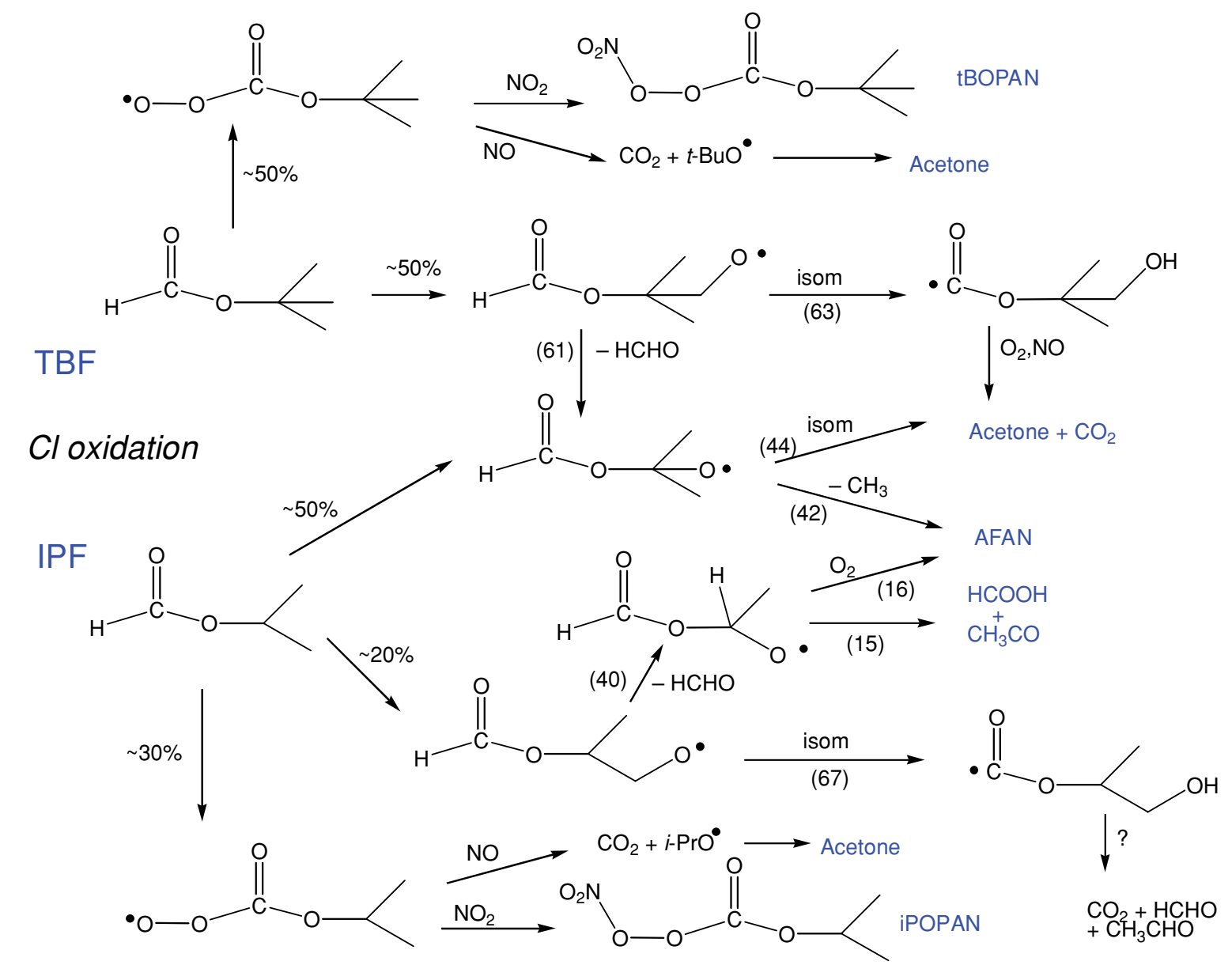

Reaction Scheme 1 Schematic of the oxidation of IPF and TBF, showing common mechanistic features. Reaction numbers correspond to those in text. [Color figure can be viewed in the online issue, which is available at www.interscience.wiley.com.] 
radicals (e.g., $\mathrm{CF}_{3} \mathrm{CFHO}^{\bullet}, \mathrm{HOCH}_{2} \mathrm{CH}_{2} \mathrm{O}^{\bullet}$ ) [43]. The present systems have extra energy available from decomposition of the acyloxy radical, so the energy that is deposited can approach the barriers for the unsubstituted alkoxy radicals $\left(\mathrm{CH}_{3}\right)_{2} \mathrm{CHO}^{\bullet}$ and $\left(\mathrm{CH}_{3}\right)_{3} \mathrm{CO}^{\bullet}$.

In the case of IPF, no products were observed that could be unequivocally attributed to this activated decomposition process. However, the possibility also exists that highly activated isopropoxy radicals could react with $\mathrm{O}_{2}$ more rapidly than thermally equilibrated radicals. This would explain the fact that the isopropyl nitrite and nitrate were typically below the detection limit. Some decomposition of hot isopropoxy to $\mathrm{CH}_{3} \mathrm{CHO}+\mathrm{CH}_{3}$ radicals cannot be totally ruled out.

Isomerization of alkoxy radicals occurs in both schemes, leading to abstraction of the formyl hydrogen. In the case of $\mathrm{HC}(\mathrm{O}) \mathrm{OC}\left(\mathrm{CH}_{3}\right)_{2} \mathrm{O}^{\bullet}$, the isomerization occurs via a five-membered intermediate. Normally this transition state would not be favorable as a result of ring strain, but the weak $\mathrm{H}-\mathrm{C}(\mathrm{O})$ bond reduces the activation energy and enhances the reaction rate. More theoretical work is clearly needed to understand the role of these strained isomerization reactions.

Overall, the oxidation of isopropyl and tert-butyl formates provides a rich chemistry. The mechanisms proposed here, while not unique, provide a description of the chemistry, which is in agreement with our understanding of ester chemistry based on previous studies.

Reaction Scheme 1 summarizes the mechanisms involved in the formation of the observed products, with branching fractions shown for the $\mathrm{Cl}$ atom reactions. In the atmosphere, where reaction will proceed by $\mathrm{OH}$ attack, it is expected that IPF will form AFAN (40$45 \%$ ), acetone (40-45\%), and formic acid (15-20\%). TBF will give a high yield of acetone and $\mathrm{CO}_{2}(80-$ $90 \%$ ). Depending on the levels of $\mathrm{NO}$ and $\mathrm{NO}_{2}$ present, small amounts of the acylperoxy nitrates may also be formed. Hydrolysis and rain-out of the soluble products should also be considered for a full understanding of the atmospheric fate of these molecules.

\section{SUPPORTING INFORMATION}

Figure S1 Plot of the yield of $\left(\mathrm{CH}_{3}\right)_{2} \mathrm{CHOC}(\mathrm{O}) \mathrm{Cl}$ versus consumption of IPF in the absence of $\mathrm{O}_{2}$. Data are shown for three experiments with $\mathrm{Cl}_{2}$ in the range (3-34) $\times 10^{14}$ molecule $\mathrm{cm}^{-3}$. The slope $(0.30 \pm 0.03)$ gives the yield of abstraction at the formyl hydrogen.

Figure S2 Plot of the yield of $\mathrm{CO}_{2}$ versus consumption of TBF from three experiments in the absence of $\mathrm{O}_{2}$. Filled circles: $\mathrm{Cl}_{2}=6.4 \times 10^{14}$; open circles: $\mathrm{Cl}_{2}=$ $1.3 \times 10^{15}$; triangles: $\mathrm{Cl}_{2}=3.2 \times 10^{14}$ molecule $\mathrm{cm}^{-3}$.
The slope $(0.49 \pm 0.05)$ gives the yield of abstraction by $\mathrm{Cl}$ at the formyl hydrogen.

Figure S3 Plot of the reciprocal iPOPAN yield against the mean ratio $\mathrm{NO} / \mathrm{NO}_{2}$ for individual photolysis periods in the reaction of IPF with $\mathrm{Cl}$ atoms in the presence of NO.

NCAR is operated by the University Corporation for Atmospheric Research under sponsorship from the National Science Foundation. Computer facilities at UNT were purchased with NSF grant CHE-0342824, and PM is grateful to the R. A. Welch Foundation (Grant B-1174) and the UNT Faculty Research Fund for support. We thank Julia Lee Taylor, Eric Apel, and an anonymous reviewer for their comments on the manuscript.

\section{BIBLIOGRAPHY}

1. Legreid, G.; Lööv, J. B.; Staehelin, J.; Hueglin, C.; Hill, M.; Buchmann, B.; Prevot, A. S. H.; Reimann, S. Atmos Environ 2007, 41, 8409-8423.

2. Japar, S. M.; Wallington, T. J.; Richert, J. F. O.; Ball, J. C. Int J Chem Kinet 1990, 22, 1257-1269.

3. Tuazon, E. C.; Carter, W. P. L.; Aschmann, S. M.; Atkinson, R. Int J Chem Kinet 1991, 23, 1003-1015.

4. Smith, D. F.; Kleindienst, T. E.; Hudgens, E. E.; McIver, C. D.; Bufalini, J. J. Int J Chem Kinet 1991, 23, 907-924.

5. Karl, T.; Apel, E.; Hodzic, A.; Riemer, D.; Blake, D.; Wiedinmyer, C. Atmos Chem Phys 2009, 9, 271-285.

6. Arp, H. P. H.; Fenner, K.; Schmidt, T. C. Environ Sci Technol 2005, 39, 3237-3244.

7. Thiault, G.; Thevenet, R.; Mellouki, A.; Le Bras, G. Phys Chem Chem Phys, 2002, 4, 613-619.

8. Zhou, S.; Barnes, I.; Zhu, T.; Bejan, I.; Benter, T. J Phys Chem A, 2006, 110, 7386-7392.

9. Gaffney, J. S.; Marley, N. A. Atmos Environ 2009, 43, 23-36.

10. Tuazon, E. C.; Aschmann, S. M.; Atkinson, R.; Carter, W. P. L. J Phys Chem A 1998, 102, 2316-2321.

11. Christensen, L. K.; Ball, J. C.; Wallington, T. J. J Phys Chem A, 2000, 104, 345-351.

12. Cavalli, F.; Barnes, I.; Becker, K. H.; Wallington, T. J. J Phys Chem A 2000, 104, 11310-11317.

13. Wallington, T. J.; Hurley, M. D.; Maurer, T.; Barnes, I.; Becker, K. H.; Tyndall, G. S.; Orlando, J. J.; Pimentel, A. S.; Bilde, M. J Phys Chem A 2001, 105, 5146-5154.

14. Picquet-Varrault, B.; Doussin, J. F.; Durand-Jolibois, R.; Carlier, P. Phys Chem Chem Phys 2001, 3, 2595-2606.

15. Picquet-Varrault, B.; Doussin, J. F.; Durand-Jolibois, R.; Carlier, P. J Phys Chem A 2002, 106, 2895-2902.

16. Tyndall, G. S.; Pimentel, A. S.; Orlando, J. J. J Phys Chem A, 2004, 108, 6850-6856.

17. Rayez, M. T.; Picquet-Varrault, B.; Caralp, F.; Rayez, J. C. Phys Chem Chem Phys 2002, 4, 5789-5794.

18. Ferenac, M. A.; Davis, A. J.; Holloway, A. S.; Dibble, T. S. J Phys Chem A 2003, 107, 63-72. 
19. Orlando, J. J.; Tyndall, G. S. Int J Chem Kinet 2010, 42, 397-413.

20. Shetter, R. E.; Davidson, J. A.; Cantrell, C. A.; Calvert, J. G. Rev Sci Instrum 1987, 58, 1427-1428.

21. Christensen, L. K.; Wallington, T. J.; Guschin, A.; Hurley, M. D. J Phys Chem A 1999, 103, 4202-4208.

22. Atkinson, R.; Baulch, D. L.; Cox, R. A.; Crowley, J. N.; Hampson, R. F.; Hynes, R. G.; Jenkin, M. E.; Rossi, M. J.; Troe, J. Atmos Chem Phys 2006, 6, 3625-4055.

23. Notario, A.; Le Bras, G.; Mellouki, A. J Phys Chem A 1999, 102, 3112-3117.

24. Sellevag, S. R.; Nielsen, C. J. Asian Chem Lett 2003, 7, 15-20.

25. Wallington, T. J.; Hurley, M. D.; Haryanto, A. Chem Phys Lett 2006, 432, 57-61.

26. Bryukov, M. G.; Slagle, I.; Knyazev, V. D. J Phys Chem A 2003, 107, 6565-6573.

27. Stemmler, K.; Mengon, W.; Kerr, J. A. J Chem Soc, Faraday Trans 1997, 93, 2865-2875.

28. Szilágyi, I.; Dóbé, S.; Bérces, T.; Márta, F.; Viskolcz, B. Zeit Phys Chem 2004, 218, 479-492.

29. Gierczak, T.; Rajakumar, B.; Flad, J. E.; Burkholder, J. B. Int J Chem Kinet 2009, 41, 543-553.

30. Rüegge, D.; Fischer, H. Int J Chem Kinet 1986, 18, 145-158.

31. Kirchner, F.; Thüner, L. P.; Barnes, I.; Becker, K. H.; Donner, B.; Zabel, F. Environ Sci Technol 1997, 31, 1801-1804.

32. Sehested, J.; Christensen, L. K.; Møgelberg, T.; Nielsen, O. J.; Wallington, T. J.; Guschin, A.; Orlando, J. J.; Tyndall, G. S. J Phys Chem A 1998, 102, 1779-1789.

33. Allen, G.; Remedios, J. J.; Smith, K. M. Atmos Chem Phys 2005, 5, 3153-3158.

34. Aschmann, S.; Atkinson, R. Int J Chem Kinet 1999, 31, 501-513.

35. Good, D. A.; Francisco, J. S. J Phys Chem A 2000, 104, 1171-1185.
36. Malanca, F. E.; Fraire, J. C.; Argüello, G. A. J Photochem Photobiol A 2009, 204, 75-81.

37. Braun, W.; Herron, J. T.; Kahaner, D. Int J Chem Kinet 1988, 20, 51-62.

38. Le Calvé, S.; Le Bras, G.; Mellouki, A. J Phys Chem A 1997, 101, 5489-5493.

39. Montgomery, J. A., Jr.; Frisch, M. J.; Ochterski, J. W.; Petersson, G. A. J Chem Phys 1999, 110, 2822 2827.

40. Frisch, M. J.; Trucks, G. W.; Schlegel, H. B.; Scuseria, G. E.; Robb, M. A.; Cheeseman, J. R.; Montgomery, J. A., Jr.; Vreven, T.; Kudin, K. N.; Burant, J. C.; Millam, J. M.; Iyengar, S. S.; Tomasi, J.; Barone, V.; Mennucci, B.; Cossi, M.; Scalmani, G.; Rega, N.; Petersson, G. A.; Nakatsuji, H.; Hada, M.; Ehara, M.; Toyota, K.; Fukuda, R.; Hasegawa, J.; Ishida, M.; Nakajima, T.; Honda, Y.; Kitao, O.; Nakai, H.; Klene, M.; Li, X.; Knox, J. E.; Hratchian, H. P.; Cross, J. B.; Adamo, C.; Jaramillo, J.; Gomperts, R.; Stratmann, R. E.; Yazyev, O.; Austin, A. J.; Cammi, R.; Pomelli, C.; Ochterski, J. W.; Ayala, P. Y.; Morokuma, K.; Voth, G. A.; Salvador, P.; Dannenberg, J. J.; Zakrzewski, V. G.; Dapprich, S.; Daniels, A. D.; Strain, M. C.; Farkas, O.; Malick, D. K.; Rabuck, A. D.; Raghavachari, K.; Foresman, J. B.; Ortiz, J. V.; Cui, Q.; Baboul, A. G.; Clifford, S.; Cioslowski, J.; Stefanov, B. B.; Liu, G.; Liashenko, A.; Piskorz, P.; Komaromi, I.; Martin, R. L.; Fox, D. J.; Keith, T.; Al-Laham, M. A.; Peng, C. Y.; Nanayakkara, A.; Challacombe, M.; Gill, P. M. W.; Johnson, B.; Chen, W.; Wong, M. W.; Gonzalez, C.; Pople, J. A. Gaussian 03; revision C.02, Gaussian: Pittsburgh, PA, 2004.

41. Johnston, H. S. Gas Phase Reaction Rate Theory; Ronald: New York, 1966.

42. Bell, R. P. The Tunnel Effect in Chemistry; Chapman and Hall: London, 1980.

43. Orlando, J. J.; Tyndall, G. S.; Wallington, T. J. Chem Rev 2003, 103, 4657-4689. 